\title{
İdeal Devletten İmkânsız Devlete: İslam İktisadında Devlet Düşüncesi
}

\author{
İsa YILMAZ* \\ Ístanbul Medeniyet Üniversitesi \\ Burak ATEŞ** \\ Türkiye Petrolleri Anonim Ortaklığı (TPAO) \\ Merve SOYLU*** \\ İstanbul 29 Mayıs Üniversitesi
}

\begin{abstract}
Öz
Bu çalışma Wael B. Hallaq'ın İmkânsız Devlet adlı eserinden yola çıkarak İslam iktisadı literatürüne önemli katkılarda bulunmuș kurucu figürlerin devlet-piyasa ilișkilerinde devlete atfettikleri role dair mukayeseli bir değerlendirme sunmayı amaçlamaktadır. Hallaq'ın görüşlerinin esas alınmasının ardında kendisinin oryantalist bir bakıș açısının ötesinde şeriat, ahlak ve piyasa ilişkilerine dair devletin rolünü de dahil eden özgün bir yaklaşım sunması yatmaktadır. Mevcut literatürde, İslam iktisadının kurucu figürlerinin devlete dair yaklaşımları da ele alındığında, İslam ve devlet daha çok soyut düzlemde ve ideal olumlu çağrışımlarıyla ele alındığı için bu çalışma İslam iktisadına dair yapılan çalıșmalarda modern devletin yapısını sorgulamaksızın özgün bir iktisadi alternatiften bahsetmenin güçlüklerini ele almaktadır.
\end{abstract}

\section{Anahtar Kelimeler}

Modern Devlet, İslam Ekonomisi, Piyasa Sistemi

\footnotetext{
* Dr. Öğr. Üyesi, İstanbul Medeniyet Üniversitesi, Siyasal Bilgiler Fakültesi, İktisat Bölümü, isa. yilmaz@medeniyet.edu.tr, ORCID: 0000-0001-7388-8539

** Uzman, Türkiye Petrolleri Anonim Ortaklığı (TPAO) Genel Müdürlügü, İnsan Kaynakları Daire Başkanlığı, bates@tp.gov.tr, ORCID: 0000-0002-7472-893X

*** Yüksek Lisans Öğrencisi, İstanbul 29 Mayı Üniversitesi, İslam Ekonomisi ve Finansı Programı, mervesoylu13@gmail.com, ORCID: 0000-0001-7010-6490
} 


\title{
From Ideal State To Impossible State: The Idea Of State In Islamic Economics
}

\begin{abstract}
This article aims to provide a comparative study on the role of state on market in the eyes of founding fathers of Islamic economics. Wael B. Hallaq's core arguments in his book 'The Impossible State' are adopted since he develops an authentic approach towards the role of state on the relationship between sharia, ethics and market beyond orientalist perspective. While founding fathers' approaches on the role of state in economics are examined, state is assumed to have transcendental, omnipotent and benevolent characters. This article, however, argues that modern state should be analyzed in Islamic economic studies with its subversive aspects.
\end{abstract}

\section{Keywords}

Modern State, Islamic Economics, Market System

\section{Extended Abstract}

Studies on Islamic economics have significantly been growing in the last couple of decades. The underlying reason behind it is related to the search for an authentic economic system through which Muslim societies develop both socially and economically in the post-colonial period. Since the global capitalist system creates inequalities both intra and intergenerationally, Islamic economics is envisaged to offer an authentic alternative through its sharing paradigm. Once initial studies on Islamic economics in the second half of the $20^{\text {th }}$ century are considered, it is obvious that the central concern is towards establishing the development of Muslim societies beyond Eurocentricity of economic development theories. Thus, some criticisms on interest, social injustice, conspicuous consumption, unequal distribution had come into the fore amongst the primary subject areas. Later in the 1970s, however, Islamic economic studies converged towards a new area, which is called financial development. As the global capitalist system gradually shifted towards financial sector, Islamic economics invariably followed the global trend by prioritizing Islamic finance as the sole institutional area for the development of Muslim societies.

As the convergence implies, the related academic studies proliferated and accumulated around Islamic financial development, hence, expectations from Islamic development through non-financial sectors remained less significant. Product development has been made mostly within Islamic financial industry to take part in the global financial system. Other issues of Islamic economics such as production, consumption, distribution and the relationship emerged out of these areas has rarely been dealt. Therefore, the link between economic activities and its interaction with other areas including politics, society, and philosophy could not be generated thoroughly. Instead, an efficiency-oriented approach on growing the share of Islamic financial industry within the global 
financial system has been adopted. Social costs of involving into such a global race has hardly been considered so far.

A normative insight into the scope of Islamic economics necessitates a wider approach on a robust economic system. For instance, capitalism as an economic system takes its intellectual roots from the Enlightenment period. Also, it adopts neoliberal values and can only be functional under a modern nation state. A similar search for intellectual origins of Islamic economics is inevitable so long as an authentic economic system is sought within Muslim societies. Based on this, the interactions of Islamic economics with market, ethics, law, society and state are important to ponder.

This study aims to provide a comparative study on the role of state on economy in the eyes of founding fathers of Islamic economics. Since state is mostly envisaged by most of the scholars in the field as an abstract institution that has full of omnipotence and benevolence characters, very few studies recognize the devastating aspects of modern state on society and economy. In the eyes of contemporary scholars of Islamic economics, state is given an ideal role just like the one which was experienced in the golden age of Islam in the prophetic periods of Madina. Therefore, state is taken for granted in the Islamic economic studies that needs no deep investigation on the role of state on market and economy. Rather, state is assumed as an institution that always shows its omnipotent and benevolent characters to the society. Thus, no objections towards the existence and role of modern state should be made in this view.

This study provides a critical approach to the abstracted and cherished idea of modern state by Muslim scholars. In doing so, Wael B. Hallaq's core arguments in his book 'The Impossible State' are adopted since he develops an authentic approach towards the role of state on the relationship between sharia, ethics and market beyond orientalist perspective. According to Hallaq, modern state is not just alien to Islamic values due to its ideological background, but also it inhibits the emergence of an authentic economic, political, legal and cultural system within Muslim societies in the $21^{\text {st }}$ century.

The development of an Islamic economic theory in the modern age must address some critical questions raised by Hallaq. First, the modern nation state created the militarism of imperial states. Second, it brought a particular cultural atmosphere that has full of Western values. Lastly, there is a liberal-capitalist global market system that cannot be easily dissociated from modern state. An Islamic economic system, therefore, should offer an alternative on how to struggle with the militarism, the cultural dominance and pervasiveness of market economy. While Hallaq is quite pessimistic in terms of the future landscape of Muslim societies, he emphasizes the morality of the sharia, which he believes as the central domain of traditional societies. An Islamic economic theory, today, should reconsider the morality of the sharia. Otherwise, Islamic economics can find no way other than the replication of modern economic and financial practices. 
This critical approach, unfortunately, did not find a resonance in the thoughts of founding fathers. Once their approaches on the role of state on economics are examined, state is assumed to have transcendental, omnipotent and benevolent characters. This article, however, argues that modern state should be analyzed in Islamic economic studies with its subversive aspects. While capitalist system gives market exchange an essential role to sustain social bond, modern state is envisaged as the guarantor of exerting the rules of market system so that a rational-bureaucratic mechanism keeps the supremacy of market system. However, an Islamic economic system suggests an ethical solution in establishing the social bond amongst Muslim societies. Thus, the design of an economic system emerges out of the Islamic moral code of conduct. Civil society, here, plays a central role instead of a rational-bureaucratic mechanism exerted by modern state. Traditional societies, in this sense, had always prioritized civil society understanding.

This study, first, clarifies the aspects which Islamic values are in conflict with the modern nation state. The next section sheds light on some experiences of pre-modern states and their interactions with economy and society. Later, the perceptions of some prominent founding fathers on the role of state in Islamic economics are examined thoroughly. The last section deals with to what extent theory making on Islamic economics is possible without considering the devastating role of modern state. 


\section{Giriş}

İslam iktisadı alanında yapılan akademik çalışmalar özellikle son yirmi yıldır ciddi bir artış göstermektedir. Bu artışta faizin baskın şekilde iktisadi faaliyetlerin çerçevesini ve toplumsal ilişkileri belirlediği küresel finansal sistemden rahatsız olan ve böylece kendine alternatif İslami finansal çözümler arayan Müslüman toplumların arayışlarının önemli bir rolü vardır. Küresel ekonomik sistemin 21. yüzyılda finansal piyasaları ön plana çıkarmasıyla finans merkezli ekonomi anlayışının yerleştiği düşünüldüğünde, İslam iktisadı çalışmalarının önemli bir boyutu küresel trende uyarak finans haricindeki iktisadi alanları geri plana atmış ve böylece akademik çalışmaların büyük bir kısmı pratik ihtiyaçlara dönük olarak ortaya çıkan yeni finansal ürünlerin geliștirilmesine odaklanmıştır. Böyle olunca, İslam iktisadı çalışmaları temelde İslami bankacllık ve finans zemininde genişlemekte, buna karşıllk üretim, tüketim ve dağılım gibi temel teorik meseleler ikincil planda kalmaktadır. Teorik açıdan düşünüldüğünde, iktisadi faaliyetin birbiriyle kopmaz bağ ve etkileşim içerisinde olduğu siyaset, toplum, felsefe ve hukuk gibi alanların iktisadi sistemle etkileşimi İslam iktisadı çalışmalarında derinlemesine araştırma imkânı bulamamıștır.

Mevcut pratiğin ötesinde normatif yönüyle bakıldığında iktisadi bir sistemi tüm boyutlarıyla anlamak ve buna uygun iktisadi politikalar üretmek bu sistemin belirtilen diğer alanlarla nasıl bir etkileşim içerisinde olduğunu kavramaya bağlıdır. Örneğin, kapitalizm iktisadi bir sistem olarak ele alındığında bu sistemin felsefi açıdan Aydınlanmacı dünya görüşünden beslendiği, ekonomik yönden neoliberal politikalara dayandığı, siyasi açıdan modern ulus devlet $^{1}$ yapısı içerisinde özgürlükçü ve demokratik çerçevede yer edindiği, hukuki olarak seküler ve hümanist bir hukuk sistemi benimsediği ve sosyolojik açıdan da Batılı değerlerin kültürel çeşitlilik adıyla hegemonik bir biçimde sunulduğu görülür. Benzer şekilde, İslam iktisadında da bu alanlara dair özgün bir iddia olması gerekirken küresel finansal sistem içerisinde alternatif finansal enstrümanlar sunarak soft kapitalist bir finansal endüstrinin somut ve

1 'Modern ulus devlet' ya da 'modern devlet' kavramı ilgili literatürde oldukça sık kullanılmasına rağmen aslında gereksiz bir tekrar olușturan totolojik bir ifadedir. Zira, çalıșmanın ileri bölümlerinde detaylı açıklanacağı üzere devlet kavramının yapısı ve işlevi modern dönemi çağrıștırır. Günümüzdeki çağrışımı itibariyle modern öncesi dönemde bir devletten bahsetmek mümkün değildir (detaylı bilgi için bkz. Poggi, 2008: 35). Tüm bunlara rağmen bu çalışma her ne kadar yalnızca devlet ifadesini kullanmanın modern çağı yansıtacağını iddia etse de modern dönemin keskin dönüștürücü etkisini vurgulamak amacıyla devlet kavramının önüne yerine göre modern ve ulus sıfatlarını koymayı tercih eder. 
pratik çözüm arayışlarına dönük entelektüel çalışmalarla sınırlı bir İslam iktisadı literatürü ortaya çıkmıştır. Dolayısıyla, İslam iktisadı araştırmaları içerisinde kayda değer bir ağırlığı olması gereken piyasa, ahlak, hukuk ve devlet gibi kurum ve kavramların günümüzdeki fonksiyonları ve etkileri hakkında yapılan teorik çalışmalar oldukça sınırlı kalmaktadır.

Bu çalışma, yukarıda bahsedilen ihtiyaçtan yola çıkarak, İslam iktisadının önemli bileşenlerinden biri olan devlet konusunu ele almayı amaçlamaktadır. Günümüzde, ekonomik sistemlerin işleyişinde devlet düzenleyici, müdahale edici, sosyal refahı sağlayıcı, iktisadi verimliliği arttırıcı ve dağılımsal adaleti yeniden düzenleyici yönleriyle kritik bir rol üstlenmektedir. Geniş çerçevede kapitalist üretim biçimlerinden farklı bir yapıya sahip ekonomik sistemlerin mevcut küresel dünyada yer bulamadığı varsayımından yola çıkıldığında, küresel olarak kapitalizme alternatif olma iddiasında olan ekonomik sistemlerin piyasa ve devlet ilişkilerinde mutlaka mevcut durumun ötesinde yeni ve özgün bir iddiaya sahip olması gerekmektedir. Bu açıdan, kapitalizmin temel karakteristiklerinden biri olan modern ulus devlet yapısını çok boyutlu bir şekilde ele almaksızın özgün bir alternatif iktisadi sistemden bahsetmek zor olacağına göre, bir alternatif olarak İslam iktisadı çalışmalarının modern devlet yapısı ve bu yapının ekonomik sistemin işleyişindeki etkisini ele alması kaçınılmazdır.

Bu gerçekten yola çıkarak İslam iktisadının kurucu figürlerinin görüşleri ele alındığında devlet ve piyasa ilişkilerinde genel olarak devlet İslami değerlerle yüklü hayırsever bir yapı olarak tasavvur edilmiş, ideal devlet özelliklerine sahip siyasi bir atmosferde bir iktisadi modelin inşa edilmesi sorununun ötesinde devlet ve piyasa ilişkileri sınırlı olarak gündeme gelmiştir. Bu durumda, modern devletin İslam'ın iktisadi alanda benimsediği değerlerle iç içe olduğu karşıtlıklar gündemden düşmüştür. Özellikle bu çalışmada görüşlerine yer verilen kurucu figürlerin gözünde devlet büyük ölçüde soyut niteliğe sahip kurumsal bir aygıt olarak düşünüldüğü için devletin olması gereken özellikleri sıralanmıştır. Oysa, modern devlet bir kurum olarak insanların bir araya gelmesiyle ortaya çıkan ve bireyler arası ilişkiler çerçevesinde etkin bir rol oynayan karmaşık bir yapıya sahiptir. Modern devletin ayrılmaz unsuru olarak görülen ulus ise "hayal edilmiş bir siyasal topluluktur - kendisine aynı zamanda hem egemenlik hem de sınırlılık içkin olacak şekilde hayal edilmiş bir cemaattir" (Anderson, 1995: 20). Devleti bu boyutlarıyla yeniden düşünmek, beraberinde modern devletin herkesin iyiliğini düşünen ideal bir devlet modeli olduğu varsayımını yıkarak ahlaki yönden sorgulanabilir ve eleştiriye açık bir model olduğu gerçeğini hatırlatacaktır. Zira modern devletin beslendiği Aydınlanmacı felsefi gelenek devleti soyut ve özel bir mantığa sahip olan bir siyasi topluluk olarak tasavvur ettiği için devleti her türlü karşı hegemonik gelişmeler karşısında ayakta tutacak ve devletin benimsediği ideolojiyi sürdürecek zemini sağlamlaștıracak politikaları ahlaki tüm kaygıların önüne koyar. Bu sayede geleneksel dönemin ideal devleti modern zamanda yerini 
çıkarları pahasına ahlak başta olmak üzere tüm değerleri araçsallaştıran bir devlet mantığına bırakır.

Modern devlet birkaç yüzyıldır alternatifsiz bir model olarak farklı coğrafyalarda etkisini göstermektedir. Küresel olarak ulus devlet özelliklerinden bağımsız hareket eden toplumsal yapılardan bahsedilemeyeceğine göre Müslüman toplumların sahip olduğu değerleri yaşatmak itibariyle ulus devletle ne ölçüde uyum içerisinde olduğu önemli bir sorudur. Bu durum İslam'ın iktisadi prensipleri ile modern devletin değerlerinin iktisadi uzantıları arasında yaşanan çatışma göz önüne getirildiğinde daha da önemli hale gelir. Bu meseleye dair akademik olarak pek çok çalışma yapılmıştır, ancak Wael B. Hallaq'ın (2019) 'Imkânsız Devlet' adlı eseri modern devletin Müslüman toplumlara yaşattığı zorlukları göstermesi açısından ayrı bir öneme sahiptir. Hallaq’a (2019) göre modern ulus devlet üzerine bina olunduğu düşünsel birikim sebebiyle İslam'a yabancı, hatta İslami değerlerin iktisadi, siyasi, hukuki ve kültürel olarak tatbik edilmesinde engelleyici bir role sahiptir.

Bu çalışma Hallaq'ın İmkânsız Devlet adlı eserinden yola çıkarak İslam iktisadı literatürüne önemli katkılarda bulunmuş kurucu figürlerin devlet tasavvuruna dair mukayeseli bir değerlendirme sunmayı amaçlamaktadır. Hallaq'ın görüşlerinin esas alınmasının ardında kendisinin oryantalist bir bakış açısının ötesinde șeriat, ahlak ve piyasa ilişkilerine dair devletin rolünü de dahil eden özgün bir yaklaşım sunması yatmaktadır. Mevcut literatürde, İslam iktisadının kurucu figürlerinin devlete dair yaklaşımları da ele alındığında, İslam ve devlet daha çok soyut düzlemde ve ideal olumlu çağrışımlarıyla ele alındığı için bu çalışma İslam iktisadına dair çalışmalarda modern devletin yapısını sorgulamaksızın özgün bir iktisadi alternatifin inşasına dair olumsuz bir kanaat barındırmaktadır.

Bu bağlamda öncelikle Hallaq'ın bahsedilen eserindeki modern devlet yapısı ve belirli yönleriyle İslami değerlerle çatışma içerisinde olduğu boyutları ele alınacaktır. Sonrasında, modern öncesi geleneksel olarak adlandırılan tarihsel dönemde devlet tecrübelerine dair yaklaşımlar sergilenecektir. Daha sonra İslam iktisadının kurucu figürlerinde devlet düşüncesi kapsamlı şekilde incelenecektir. Son bölümde ise mevcut yönüyle iktisadi sistem dahil olmak üzere İslami bir alternatif iddianın modern çağda ulus devlet gerçeğiyle hesaplaşmadan ortaya çıkmasının imkansızlığından bahsedilecektir.

\section{Modern Devlet ve İslam Devleti: Wael B. Hallaq Perspektifi}

Hallaq, İmkânsız Devlet olarak Türkçeye tercüme edilen eserinin giriş kısmında çalışmasının temel fikrini aktarırken 'temsil ettiği değerler bakımından ele alındığında modern devletten tanımı ve kapsamı itibariyle İslami bir devlet çıkarmanın hem bir imkânsızlık barındırdığını hem de bunun çelişkili bir tamlama olduğunu' iddia eder (Hallaq, 2019:13). Buna göre, modern İslami devlet kavramsallaştırması modernitenin ve İslam'ın sahip olduğu değerlerin 
birbirine karşıtlık oluşturması yönüyle çelişki oluşturmaktadır. Bugün dünya nüfusunun beşte birini oluşturan Müslüman toplumların modernitenin içine doğduğu, dolayısıyla istese de istemese de bu modern projenin bir parçası olduğu göz önüne alındığında (bkz. Arslan, 2015) bu gerçek ile yüzleşmek kaçınılmazdır. Hallaq, modern zamanda İslami devlet fikrinin bir çelişki oluşturmasının nedenini ise modernitenin ahlaki açmazlarına bağlamaktadır. Belirtilen ahlaki açmazlar siyaset ve ekonomiyi ilgilendiren alanlarda da aşikardır. Dolayısıyla, Müslüman toplumların özellikle siyaset ve ekonomide özgün bir söyleme sahip olması için modernitenin maruz bıraktığı ahlaki sorunlara karşı mutlaka bir cevap üretmesi gerekmektedir (Hallaq, 2019: 13-15).

\section{Modern Devlet ve Birey}

Modernlik, eskinin sadece geçmişte bırakılması değil, aynı zamanda onun yıkılmasını ifade eden bir kavramdır (Ertugay, 2016: 163). Modernleşme sürecinin politik uzantısı olan modern devletse Machiavelli'den Hobbes'a ve sonrasında Weber ve Poggi'ye kadar uzanan zaman diliminde 'belirli bir toprak ve belirli bir halk üzerinde meşru güç kullanma tekeline sahip insan organizasyonu' olarak tanımlanır. Modernleşmenin siyasal alandaki tezahürü olarak modern devlet güçlü ve merkezi bir birlikteliği toplumsal örgütlenmenin en iyi bir biçimi olarak görür. Artık tek üst kimlik toparlayıcı olarak siyasi kimlik vardır ve bu kimliğin belirleyicisi de devlettir. Aile, din, cemaat, etnik topluluklar gibi kimlikler ise alt kimlikler haline gelmiştir (Erdoğan, 2006: 33).

Geleneksel toplumlara bakıldığında Müslüman şahsiyet ile İslam düşüncesine göre inşa edilmiş toplum ve siyasi otorite arasında çekişmeden ziyade bir ahenkten bahsedilebilir. Çünkü İslam'ın insan anlayışında kul olma bilincine sahip kişi, hür cüz-i iradesi ve seçme melekesine sahip olarak yaptığı her işten dünyada ve ahirette sorumlu tutulacağının farkındadır. Bundan dolayı kendi içinde uyumlu ve dengeli bir hayat yaşamaya dikkat edeceği gibi toplum ve tabiatla olan ilişkisinde de bunu gözetmeye çalışır. Bu da doğal olarak birbiriyle uyumlu ilişkileri ortaya çlkaracaktır (Köse, 2018: 28).

$\mathrm{Bu}$ tarz uyumlu ilişkileri doğuracak toplumun ve siyasal organizasyonların oluşumu için aile kurumuna ihtiyaç vardır. Aile, var olabilmek ve varlığını sürdürebilmek için birbirlerine muhtaç insanların meydana getirdiği temel bir sosyal kurumdur. Nikâhtan mirasa kadar naslarda yer alan düzenlemeler İslam'ın ailenin kurulmasına ve korunmasına yönelik ayrıntılı hükümler içerdiğini göstermektedir (Köse, 2018: 28).

Modern devlet, başta aile, din ve gelenekten oluşan ara kurumları kullanılamaz hale getirerek ortadan kaldırmış, bu boşluğu ise merkezileşmiş büyük bürokratik düzenle doldurmuştur. Ara kurumların ortadan kalkmasıyla sistemli bir yalnızlaştırmaya maruz kalan insanın devletin totaliter yapısı karşısında direnme gücü oldukça sınırlı kalmıştır. 
Modern devletin gelişmesi ile ara kurumların gelişmesi arasında yaşanan ters orantı sebebiyle akrabalık, inanç gibi sistemleri olgunlaştıran toplumsal gruplar ne kadar zayıflarsa modern devlet de o derece ön plana çıkmıştır. Bu amaç üzere hareket eden modern devlet birey merkezli ve eşitlikçi tavrıyla toplumda var olan doğal hiyerarşileri yıkmış ve bireyi savunmasızlaştırmıştır (Ertugay, 2016: 171). Sonuç olarak saygınlıklarını ve toplum üzerindeki belirleyici rollerini kaybeden geleneksel kurumların yerini artık toplumun kılcal damarlarına kadar nüfuz eden ve gücünü her alanda hissettiren modern devlet almıştır.

\section{Modern Devletin Temel Özellikleri}

Modern devlet tamamen Avrupa kökenli, yeni ve belirli bir politik ve politik-kültürel düzenlemenin ortaya çıkış sürecini temsil eder. Dünyadaki başka hiçbir medeniyet bu belirli politik düzenlemeyi kendi başına üretememiştir. Coğrafi ve beşerî terimlerle tanımlanan Avrupa, devletin ilk kez yaratıldığı ve daha sonra geliştirildiği ve Avro-Amerika'nın halen paradigmatik devletin ev sahibi olduğu münhasır laboratuvardır (Hallaq, 2019: 57). Bu yönüyle, Carl Schmitt'in (2007) de belirttiği gibi modern devlet kökenleri itibariyle Batılı olmak zorundadır.

Belirli politik ve ideolojik yapılarla devam eden modern öncesi yönetim biçimlerinden farklı olarak modern devletin benzersiz bir gayrişahsi karakteri vardır ve meşruiyetinin kalbinde soyut bir kavram yatar. Bu soyut kavram devletin alametifarikası olan 'egemenlik' kavramıdır. Bu kavram da Avrupa deneyimi altında üretildiğinden Avrupa menşeilidir. Modern devlet, ulus iradesinin ve kaderinin tek faili olarak devleti somutlaştırması fikri etrafında inşa edilmiştir. Kavramın var olabilmesi, akla yatkın hale gelebilmesi için, ulus iradesinin ya köleleştiren bir aktörden veya zalim bir yönetimden kurtulmuş olması lazımdı ki burada imdada yetişen Amerikan ve Fransız Devrimleri örneği olmuştur. Böylelikle modern devlet, egemenliğin varlı̆̆ını kabul etmek ve bir ulusun kolektif kaderi olan kitlesel iradeyi kapsamak zorunda kalmıştır (Hallaq, 2019: 60-61).

Modern devletin egemenliği sürdürebilmesi için iki yapının varlığına ihtiyacı vardır: Ulus ve devlet. Egemen olan, kendisini var eden düzenli yasaya dayanan ulus devlet artık kendi eylemlerini diğer bütün öznelerin eylemlerinden üstün görecektir. Bu süreçte egemen irade aslında Hıristiyan iradenin yerine geçmekten farklı bir şey yapmamıştır. Her modern kavram gibi Aydınlanma öncesindeki Hıristiyan ritüelleri aynı biçimde otoriter kuvvetlere sahip kaynaklar tarafından ikame edilmiștir. Schmitt bu durumu "modern devlet teorisinin bütün kayda değer kavramları, sadece tarihsel gelişimleri yüzünden değil, aynı zamanda sistematik yapıları sebebiyle sekülerleşmiş teolojik kavramlardır- teolojiden devlet teorisine transfer edilmişlerdir, mesela kadir-i 
mutlak Tanrı kadir-i mutlak yasa koyucu haline gelmiştir" şeklinde ifade etmiştir (Schmitt, 1985: 36; akt. Hallaq, 2019: 64).

Kendi kendinin amacı olan devlet, mutlak oluşumunun sayesinde, sadece kendi varlığını ve kendi metafiziğini bilir. Bu durum devleti şiddetin sınırlarını çizmesinde tek yetkili yapmıştır. Devlet şiddete dayalı cezayı uygulamada en büyük aktördür. İlahi emirlerden doğan bir cezayı bile iradesi ile kaldırabilir veyahut bunu benimseyebilir. Burada, devlet ilahi iradeyi tasdik edendir. Kendini tanrıların tanrısı olarak görür. Egemen irade yeni tanrıysa, o halde devletten başka tanrı yoktur. Dolayısıyla da şiddet uygulama, ona sınırlar çizme ve egemen yasal iradeyi kullanma hakkı modern devletin en temel özelliklerindendir (Hallaq, 2019: 67-68).

Modern devlet, şehirli nüfusun artmasıyla birlikte kontrolünü kaybetmemek adına taşraya kadar uzanan polis aygıtını kurmuş ve bu aygıtı sağlamlaştırmak üzere aynı zamanda devasa bir hapishane sistemi meydana getirmiştir (Ergut, 2015). Var olan fiziki gücün yeterli olmadığını fark eden Avrupalı yöneticiler bu açığı kapatmak için eğitim üzerine de düşünmeye başlamıştır. Beraberinde, iyi hal üzerine eğitilen ve kapitalist sistem içerisinde üretme kabiliyetine erişecek kesim okul sistemi sayesinde oluşmuştur. Polis aygıtının çoğalmasına eş zamanlı olarak okullar da çeşitli biçimlerde çoğalmaya başlamış ve 19. yüzyılın sonuna gelindiğinde tüm toplumlarda eğitim ve okul birbirinden ayrılmaz bir bütün olarak kabul edilmiștir. Artık ilköğretim yasayla zorunlu hale gelmiş, böylece Avrupa toplumları genç nesle belirli fikirleri ve ideolojileri daha kolay biçimde tanıştırmıştır. Daha öncesinde aile içinde ya da kilisede eğitimi alma dönemi artık son bulmuştur (Althusser, 1994: 3346). Ancak bunca çabaya rağmen ne polis faaliyetleri ne de okullaşma oranı istenilen seviyeye gelmemiştir. Batıda yaşanan bu durum benzer şekilde Osmanlı'dan cumhuriyetin kuruluş sürecine geçildikten sonra da yaşanmıştır. Seküler devlet her ne kadar eğitim üzerinden yeni ideolojisini genç nesillere aktarma çabasına girse de geleneksel eğitim kurumlarının sivil alanda baskı altında da olsa devam etmesi cumhuriyet sonrası Türkiye'sinde arzulanan orana hiçbir zaman kavuşamamıştır (Karpat, 2006: 444). Ancak yine de devletin asli görevi eğitim üzerinden genç neslin vatandaşlık bilincini oluşturmaya devam etmektedir.

Modern devletin bu denli güçlü toplumsal dönüştürücü projesiyle birlikte yoksulluk artmış ve toplumsal huzursuzluk baş göstermeye başlamıștır. Bu durum Fransız devrimiyle sağladıkları ayrıcalıkları kaybetmeye niyetleri olmayan politikacıları hızlı bir sosyal güvenlik ağı ve daha da önemlisi halk sağlığı kurumları ve uzmanlaşmış hastaneler inşa etmeye sevk etmiştir. Bu bağlamda, mevcut toplumsal rahatsızlıkların önüne geçmek ve yeni tür devlet aygıtları ile disipline edici gücünü sağlamlaştırmak adına tüm Avrupa ülkelerinde refah devleti politikaları belirlemeye başlamışlardır. Her biri kendine has alanlarda işlevsellik gösteren hastaneler, hapishaneler ve okullar aslında 
Avrupa merkezci ideolojik iddialara sahip bürokratik makinenin ardında birlikte hareket etmişlerdir (Foucault, 2006).

Hallaq tüm bunlardan hareketle şu sonucu çlkarır: eğitim yoluyla ve bürokratik kurumların olgunlaşmasıyla birlikte devlet, bir vatandaş kimliği yaratmış ve gönüllü, sadık ve faydalı bireyler yetiștirmiștir. Modern ulus devletle birlikte artık monark gibi somut bir yönetici yoktur, bunun yerine benzer işleve sahip toplumsal ve bürokratik kurumlar vardır. Ancak bu tür kurumlar her zaman devletin kontrolünde rollerini icra eden kurumlar oldukları için hâkim gruplar devleti ön plana çıkartarak yine konumlarını korumuştur (Hallaq, 2019: 178).

Devlet eğitim vasıtasıyla çocuklara vatan sevgisini de aşılayarak, devletin çıkarlarını, önceliklerini ve bilhassa milliyetçiliği telkin eder ve böylece ailenin ataerkilliği yerini devletin şefkatine bırakır (Hallaq, 2019: 182-183). Milliyetçiliği de ulus devletin bir yansıması olarak gören Hallaq devlet ile milliyetçiliği sadece ikiz kardeş gibi görmekten öte birbirinin içine yerleșmiş ve bir madalyonun iki yüzü olarak tanımlar. Ona göre milliyetçilik hem bireyi hem de topluluğu yutar. Milliyetçilik tıpkı hukuk gibi her yerdedir ve devlet gibi bir metafizik arka planı vardır. (Hallaq, 2019: 185-186). Sahip olduğu metafizik sayesinde devlet fenomeninin gerekli ve dahili bir parçası olarak gelişen milliyetçilik kaybolan geleneksel dünyanın yerine geçen bir anlam dünyası olmuştur. Bundan dolayı ulus olmadan devlet olmaz ve modern devlet her zaman ulus-devlet olmak zorundadır, çünkü milliyetçilik olmadan devletin hayatta kalma şansı tıpkı kanser hastasının tedavi görmeden hayatta kalma şansı gibidir (Hallaq, 2019: 189-190).

\section{Şeriat, Modern Hukuk ve Ahlak}

Batı Avrupa'da ortaya çıkan ve tüm dünyayı etkisi altına alan modern proje insanın pratik yaşamında getirdiği birçok teknik ve teknolojik kolaylığa rağmen çeşitli düzeyde sosyal çözülme ve sorunu da beraberinde getirmiştir. En göze çarpan biçimiyle modernite bilim dünyasını, ekonomik, siyasi ve sosyal hayatı ve tüm bu alanları hakimiyeti altında tutan hukuk alanını ahlaktan bağımsızlaștırarak ahlakı ikincil bir konuma itmiştir. Newtoncu düşünce ile birlikte maddenin değerden ve ruhtan arındırılması ve "olan" ile "olması gereken" ayrımının ortaya çıkması dikkate alındığında ahlakın geleneksel ve tanrısal arka planının yok edilerek insan aklıyla keşfedilen objektif kanunlara dayanan pozitif bir norm haline geldiği görülür. Bununla birlikte, ulus devlet fikri üzerinde somutlaşan egemen iradenin bu yeni pozitif norm alanının yegane kaynağı olması süreci özelde hukuk-ahlak alanının farklılaşmasını ve ulus devlet düşüncesinin yaşam alanının oluşturulmasına, genelde ise modern projenin olgunluğa erişmesine yol açmıştır. 
Batının Aydınlanma düşüncesi etrafında ortaya koyduğu modernite projesi ile yeni bir küresel dünya düzeni kurması sonrasında İslami yönetim paradigmasının beslendiği felsefi kaynağın şeriat olmaya devam etmesi modern dönemde Müslüman toplumların devlet inşası çabasında bir tezat olarak karşılarına çıkmıştır. Hallaq, ahlaki bir hukuk tarafından çerçevesi belirlenmiş bir dünya görüşü olarak şeriata ayrı bir önem verir. O'na göre şeriatta hukuki olan, ahlaki olanın bir aracıdır ve bu durumun aksi mümkün değildir (Hallaq, 2019: 37). Bir başka deyişle şeriatın belirlediği genel ahlaki kaideler değiştirilemeyen sabitelerden sayılırken, ikinci ve tamamlayıc bir düzeye sahip olan yasal normlar (hukuk) zamanın ve mekânın talepleriyle uyumlu olarak düzenlenebilecektir.

İslam'a göre şeriat Allah'ın saf ve basit yasasıdır. Bununla birlikte şeriat ahlaki bir kanundur ve İslam hukuku olarak adlandırdığımız hermenötik, kavramsal, teorik, pratik, eğitimsel ve kurumsal sistemleri oluşturur. Şeriatın büyük projesi Allah'ın ahlaki iradesini tanımaya yönelik ahlaki-yasal bir yapı inşa etmektir (Hallaq, 2019: 99).

Oldukça kapsamlı bir yapıya sahip olan şeriat karşısında hukuk modern dünya için yeterli bir alan olarak kabul edilse de şeriatın yerini alabilecek niteliğe sahip bir sistem değildir. Bu yüzden günümüz Müslümanları tarih boyunca kullanageldiği bir kavram olarak şeriat yerine modern devlet sisteminin benimsediği hukuku ve onun içinde münhasıran kuvvetler ayrılığı ilkesini benimserse şimdiye dek kattığı faydadan daha azına tamah etmek zorunda kalacaktır. Zira, modern hukuk kendi menfaati ve sürekliliği için devletin egemenliğini ve gücünü temsil ediyorken şeriat ise ne bir sultana ne de bir politik güce hizmet etmekte, ancak bunlardan öte insanın özgürleştirilmesini ve güçlendirilmesini öncelemektedir. Bu zaviyeden bakıldığında şeriat salt anlamıyla demokratik olmaktan çok modern devletin ve modern hukukun kavrayamayacağı şekilde insanı önceleyen bir yapıya sahiptir (Hallaq, 2019: 132). Ayrıca, İslami "yasama” kuvvetinin paradigması olan şeriat, siyasi bir iradeye sahip olmadığı gibi devletin iradesiyle dahi ilgilenmezdi. 0 politikadan çok toplumla ilgiliydi. Modern proje ise hukuki ahlak çağından politik çağa keskin bir dönüşümü temsil etmektedir (Hallaq, 2019: 170).

Hallaq modern ulus devlet olgusunun inkârı mümkün olmayan varlığı ve şeri yasa düzeni kurma yükümlülügü içindeki Müslümanların modern ulus devlet fikrinin İslam tarihinin erken dönemlerinde tecrübe edildiğine dair anakronik yaklaşımlarını ve modern devlet fikrini zamansız bir fenomen olarak ele almalarını eleştirmiştir. Hallaq İslam'ın kendine has tanrısal bir inancı temsil ettiğini ve inanılan Tanrının tek yasa koyucu otorite olduğunu ve yine bu bağlamda Tanrının yasalarının kurumsallaşmış bir formu olan şeriatın Müslümanlar için genel bir ahlaki alan oluşturduğunu ifade etmektedir. Bu ahlaki alan ise öylesine geniştir ki hukuki zemini teşkil etmesi hasebiyle fertlerin siyasi, iktisadi ve sosyal yaşamına bütünüyle içkindir. Dolayısıyla şeriatın 
kendine has metafizik bir arka planı vardır ve bu ahlaki olarak bir paradigmayı temsil etmektedir.

Modern devlet ise İslam'dan farklı olarak başka bir paradigmayı temsil etmektedir, zira hem çıkış yeri (coğrafi) olarak hem sistematiğini geliştiren gelenek bakımından hem de epistemolojik olarak Avrupalıdır; yani etno-merkezcidir. Modern devlet fikri kendine özgü bir biçim, içerik ve dinamiğe sahiptir; öyle ki bu durum İslam'dan farklı bir metafiziğe ve ahlaka sahip olduğunu ve dolayısıyla farklı bir paradigmayı temsil ettiğini kanıtlar niteliktedir. Zira modernite ve modern sürecin ortaya çıkardığı devlet fikri Müslümanların felsefesini, bilimini, iktisadi ve siyasi hayatını ve sosyolojik olarak tüm yasa/şeriat yapılanmalarını etkilemiş ve sorgulamaya alarak yapısal olarak kırılmaya sebebiyet vermiştir. Bu sebeplerle Hallaq İslam'ın yönetim anlayışının yani kurumsal olarak şeriat ile modern ulus devlet fikrinin iki farklı paradigmayı temsil etmeleri dolayısıyla bu iki paradigmanın bir arada olmasını ontolojik olarak çelişkili ve imkânsız bulur.

\section{İslami Devlet ve Ümmet}

Hallaq'in düşüncesinde ulus devlet doğuşu itibariyle modern çağın bir ürünü olduğu için İslami devlet hiçbir zaman var olmamıștır. Bu yönüyle İslami devlet söylemi ancak anakronik bir yaklaşımdan ibarettir. Bu yüzden, İslami yönetim daha doğru bir kavramsallaştırma olur.

İslami yönetim, yasal, politik, sosyal ve metafizik temeller açısından modern devletten farklıdır. Modern devlette ulus varken İslami yönetimde ümmet vardır. Ümmet sınırları şeriat tarafından belirlenmiş ve hem soyut hem de somut bir kavram olarak karşımıza çıkar (Hallaq, 2019: 96). Tabi burada ümmet başlangıçta ulus devlet gözüyle bakıldığında şeriata hizmet eden bir araç olarak anlaşılabilir. Halbuki bunun ötesinde, ümmet ne kendisi egemenlik taşır ne de modern devletteki anlamıla kendine has hukuki bir irade sahibidir. Ümmet anlayışında egemen olan Allah'tır ve 0 tektir. Bu açıdan ümmet yatay düzlemde birbirleriyle eşit seviyede bulunan ancak dikey düzlemde Allah'a yakınlık manasında takvanın tek ölçüt olarak insanları ayrıştırdığı müminler topluluğu olarak tanımlanır (Hallaq, 2019: 97). Bu açıdan bakıldığında "İslam tarihinde ülke tek bir yer, millet ise bir halk veya ümmettir" (Vatikiotis, 1998: 48).

\section{Modern Dönemde İslami Devlet Yönetiminin İmkansızlı̆̆ı}

Hallaq, İslami yönetimin modern dünyada Müslüman toplumların ideallerini gerçekleştirme noktasında siyasi bir otorite olarak ortaya çıkması konusunda karamsardır. Hali hazırda İslami yönetimin modern dünya sistemi içerisinde inşa edilebileceği varsayılsa dahi bu durumda İslami yönetim üç zorlukla karşılaşacaktır. İlki, güçlü emperyalist devletlerin militarizmi, ikincisi dış kaynaklı kültürel müdahaleler ve son olarak liberal-kapitalist dünya pazarı. Bu üç zorluk birbiriyle yakından alakalı ve birbirine bağımlı aşılması gereken sorunlardır. Şimdiki dünya güç dengesi Schmittçi bir devletten yana olduğu 
sürece İslami yönetim sürekli bu zorluklarla yüz yüze kalacaktır. Bu zorluklar arasında özellikle kültürel müdahale düşünüldüğünde dahi İslami yönetimin hedonizm, materyalizm ve narsizme karşı nasıl bir tavır takınacağı önemlidir. Benzer şekilde liberal kapitalist dünya pazarının getirdiği zorlukların aşılması ve yerine özgün bir alternatifin sunulması da bir o kadar önemlidir. İslami yönetim kendi ekonomi modelini dar çevrede uygulayabilse dahi dünyaya hâkim olan ahlaki olarak bozuk bir kapitalist düzenle yarışmak zorunda kalacağı bir gerçektir (Hallaq, 2019: 252-253).

Müslümanlar yaşam tarzlarını sosyal, politik ve ekonomik sahada organize etmek isterlerse Hallaq'a göre şu iki durumla karşı karşıya kalacaktır. İslami yönetim ya modern devlete ve onun ürettiği dünyaya yenik düşecek ya da modern devlet İslami yönetimin başta ahlak olmak üzere politik ve ekonomik kavramlarını tanımak zorunda kalacaktır. Hallaq şu an itibariyle birinci seçeneğin Müslüman entelektüeller tarafından kabul edildiğini, ikinci ihtimalin ise gerçekleşmesinin daha az olası olduğunu düşünmektedir. İslami bir yönetim gerçekleşse dahi küresel dünyanın baskısı altında kalacağı bir gerçektir (Hallaq, 2019: 266-267).

\section{Modern Öncesi Dönemde Devlet ve İşlevi}

Hallaq'ın tasvir ettiği modern devlet İslami sistemlerin toplumsal hayatta yerleşik hale gelmesinde ciddi bir engel teşkil etmektedir. Bu yönüyle Hallaq tarihin sonunu ilan eden, Aydınlanmacı ve evrenselci Batı düşüncesi karşısına bir alternatif sunabilme imkânı konusunda kötümser bir tavır takınmakta, ancak modern projenin Müslüman dünyaya getirdiği çok temel bazı zorlukların aşılmasını gerekli görmektedir. Bu zorlukların aşılması noktasında şeriatın ahlakiliğine vurgu yapan Hallaq alternatif bir yönetimin imkansızlığını gerekçeleriyle açıklamaktadır. Bu durum modern öncesi dönemlerde devlet yapılarını ve işlevlerini akla getirmektedir. Bu bölüm modern öncesi dönemde devlet düşüncesi, devletin temel özellikleri ve etki alanlarına dair büyük ölçüde Ahmet Davutoğlu'nun (1994) Diyanet İslam Ansiklopedisi'nde yer alan devlet maddesinde sunduğu çerçeveden beslenen bir açıklama getirerek modern devlet ile modern öncesi dönemde devlet pratiklerinin ve gayelerinin farklılığını vurgulamayı amaçlar.

\section{Tarihi-Dini Temelli Devlet Yapısı: Dârülislam}

İslam tarihi açısından devlet örgütlenmesinin seyri incelendiğinde iki görüş ön plana çıkmaktadır. İlk görüş, devlet örgütlenmesinin hicretle birlikte ortaya çıktığı ve Medine toplumunun gerçek anlamda örgütlenme özelliklerine sahip olduğunu iddia ederken, ikinci görüş Hz. Peygamber'in siyasi olmaktan çok dini bir lider olduğunu ve yaşadığı dönemde devlet örgütlenmesinden ziyade cemaat örgütlenmesini gerçekleştirdiğini iddia etmektedir. Bu anlayış farklılığının sebebi devleti farklı şekilde tanımlamaktan geçmektedir. Birinci görüş devleti evrensel anlama sahip bir siyasi güç örgütlenmesi olarak 
tanımlarken, ikinci görüş devleti modern millet-devlet yapılanmasından hareket ederek açıklar (Davutoğlu, 1994: 236).

İslam tarihinde devlet oluşumunun Akabe biatlarıyla beraber başladığını varsayan düşünceye göre Medine toplumu Hz. Peygamber'in önderliğinde devlet yapılanmasının gereklerini ortaya koymuştur. Ancak bu yapılanma Batı siyaset literatürü içerisindeki devlet düşüncesinden farklı nebevi özelliklere sahip siyasi bir anlayışın ve kültürün sonucu oluşmuştur. Batı'daki imparatorluk, şehir devletler ve millet-devlet anlayışlarından farklı özelliklere sahip olan Medine toplumunun özünde Hz. Peygamber'in teori ile pratiği, siyasi ideal ile siyasi gerçekliği birleştiren uygulamaları vardır. Örneğin Hegel'in felsefi temelini işlediği millet-devlet görüşünde devlet toplumdan bağımsız, soyut ve baskın bir karakter taşırken, İslam'ın anlayışında devlet ahlaki ve sosyal idealleri gerçekleștirmek için bir araç olarak görülür (Davutoğlu, 1994: 236).

Batı siyasi tarihinde kendi özel coğrafi ve toplumsal koşulları içerisinde ortaya çıkan devlet mefhumunun toplumdan bağımsız ve soyut niteliği devleti kendi başına bir amaç olarak karşımıza çıkarırken İslam tarihinde kavramsal sınırları Batı siyasi hafızasına dayanan böylesi bir devletten bahsetmek mümkün değildir. Bu açıdan hilafet dönemindeki devlet anlayışının modern zamandaki millet-devlet temelli milletlerarası sistemden birçok yönüyle farklı olması hilafet sistemi içerisinde nasıl bir siyasi örgütlenmenin olduğu sorusunu da akla getirecektir. Bu durumda karşımıza özgün bir kavram olarak dârülislam çıkmaktadır. Dârülislam en temelde birbirinden bağımsız iktidar alanları olan ve çoklu siyasi örgütlenmenin gerçekleștiği siyasi bir zeminden farklı olarak daha kapsamlı bir siyasi-hukuk alana işaret eder. Bu yaklaşım modern devlet anlayışının sunduğu etnik kimliğe dayalı ve belli sınırlar içerisinde iktidar alanına sahip çoklu millet temelli siyasi örgütlenmelerden farklı olarak millet-devletin yerine milletlerarası bir düzen önermektedir. Bu düzene göre yapılacak siyasi bir tasnif Müslümanların hakimiyeti altında İslam hukukunun uygulandığı yer olarak dârülislam ve gayri Müslim bir yönetimin altında ve İslam ahkamının uygulanmadığı yer olarak dârülharp kavramlarını ortaya çıkarır (Özel, 2019: 80).

Hilafet üzere yönetilen tüm siyasi yapılanmalarda bu tasnifin siyasi, iktisadi ve toplumsal alanlarda belirleyici olduğu görülür. Emeviler, Abbasiler, Selçuklu Devleti ve Osmanlı Devleti gibi İslam tarihindeki pek çok siyasi örgütlenmelerin dârülislam ve dârülharp esasına göre siyasi politikaları ve ilişkileri belirlediği düşünüldüğünde bu ayrımın geleneksel dönemde modern devletin izlerine dair hiçbir bulguya rastlanamayacağını da göstermektedir.

Modern döneme değin yerleșik olan dârülislam ve dârülharp anlayışı hilafetin ortadan kaldırılmasıyla birlikte Müslümanların devlet anlayışında önemli değişmeler meydana gelmesiyle etkisini yitirmiştir. Sömürgeci döneme denk gelen hilafetsizlik döneminde ümmet düşüncesi yerini millet-devlet 
örgütlenmesine bırakmıştır. Hukuki ve ahlaki hedefleri olan bir devletten modern milletlerarası bir sistemin unsuru olan devlet anlayıșına geçilmesiyle alternatif bir dünya sistemi sunan dârülislam anlayışı yerini sömürge zihniyeti tarafından geliştirilen milletlerarası sistemin anlayışına bırakmıştır. Artık tarihi-dini temelli devlet yerine millet-devlet fikrini benimseyenler modern çağın gereklerine uyarak devletin İslami-ahlaki idealleri gerçekleştiren bir araç olduğu anlayışını terk etmişlerdir. Pakistan örneğinde görüleceği gibi buna karşı çıkanlar ise İslami devlet, dârülislam ve hilafet anlamında alternatif bir sistem sunmaktan ziyade İslami esaslara bağlı millet-devlet düzeni kurmuşlardır. Böylelikle tek dârülislamdan tek tek dârülislamlara doğru bir olgu ortaya çıkmış ve ümmet fikri etrafında modern zamana alternatif bir siyasi ve hukuki düzen oluşmamıştır. Bunun kaçınılmaz sonucu olarak günümüzde İslam dünyasının devlet anlayışı toplumdan topluma farklılık göstermektedir.

\section{Millet-Devlet Yapısı}

Millet-devlet kavramı Avrupa'da feodal zihniyetin çözülmesiyle birlikte ortaya çıkmıştır. 1648 Vestfalya Antlaşması ile Avrupa'daki milletlerarası sistemin temel siyasi birimi haline gelen millet-devlet kavramı halen günümüzde geçerliliğini korumaktadır. Bunun bir neticesi olarak artık devlet kavramı millet kavramından bağımsız düşünülemeyecek duruma gelmiştir:

Modern anlamda millet-devletlerin oluşumu, X. yüzyıldan XVII. yüzyıla kadar süren medeniyet dönüşümünün siyasî boyutudur. Avrupa'daki bu yeni devlet sisteminin ahlâkî-dinî temeli Protestanlık, bilimsel-entelektüel temeli Galile'nin hareket teorisine dayalı evren görüşü, sosyopolitik temeli sınır esasına dayalı hânedan/millet mutlakiyetçiliği, sosyoekonomik temeli ise ticarî kapitalizm denilen merkantilizmdir. Bu dönemde millet-devletin iç yapısı ile ilgili siyaset teorisi özellikle Makyavel, Hobbes ve Bodin tarafindan geliştirilirken bu devlet yapısına dayalı milletlerarası sistemin teorik öncülüğünü Braun, Vasquez, Suarez, Gentilis ve özellikle Grotius yapmıştır (Davutoğlu, 1994: 236).

Millet-devlet fikrini bir siyaset sistemi olarak zirveye taşımada Hegel'in rolü oldukça önemlidir. Hegel ahlaki idealleri gerçekleştirmede devleti hayatın merkezine yerleştirerek onu bir nevi Tanrı'nın yeryüzündeki tezahürü olarak görmüştür ve devletten başka bir sosyal varlığa hayat hakkı tanımamıştır. Öte yandan Hegel'in aşkın devlet anlayışına alternatif olarak sunulan liberal ve faydacı felsefelerdeki devlet anlayışı incelediğinde her iki devlet anlayışının ortak özelliğinin belli sınırlar içerisindeki hakimiyete dayalı millet-devlet kavramı olduğu görülecektir (Davutoğlu, 1994: 236).

\section{Tarihsel Olarak Devletin Siyasi Bir Mefhum Haline Gelmesi}

İslam'ın erken dönemdeki devlet kavramının kullanımı ile modern zamandaki devlet kavramı arasında bir anlam farklılığına dikkat çeken Davutoğlu, devlet kavramının siyasi bir mefhum hale gelmesini üç safhada inceler. İlk safhayı, 'zafer, güç veya hakimiyetin el değiştirmesi' olarak tanımlar. Hakimiyetin 
Emevilerden Abbasilere ihtilal yoluyla geçişini bu safhaya örnek gösterir. İkinci safhada devlet, sürekliliğini ortaya koyan bir anlam kazanmıș ve nihai siyasi otorite için kullanılmaya başlanmıştır. Abbasilerin zayıflamasıyla birlikte devlet kavramı bir hanedanlığı veya onun hakimiyetini temsil etmiştir. Bununla birlikte Osmanlıların kullandığı Devlet-i Al-i Osman tabiri de bu evredeki süreklilik manasını ihtiva etmektedir. Son olan safha ise devlet teriminin çağdaş siyaset literatüründeki kullanımıdır, öyle ki artık bu evrede kavram tamamen millet-devlet esasına dayalı 'milletlerarası sistemin her bir unsuru' anlamını karşılamaktadır. Her ne kadar kazanılan bu anlam evrenselleşse de her milletin tarihi ile uyum sorunu da yaşamaktadır. Dolayısıyla farklı bir siyasi kültür ve ahlak esası üzerine bina edilen İslam medeniyeti ile modern dönemde anlam kazanan devlet kavramı arasında ciddi bir algılama farkı ortaya çıkmış olacaktır. Böylelikle bu tarihi süreç içerisinde iki ana kutup etrafında görüş ortaya çımıştır. Birinci görüş, devleti mahiyeti ve özü itibariyle mutlak değer ifade eden soyut ve aşkın bir kurum olarak görürken ikinci görüş ise devleti muayyen sosyal işleri üstlenen siyasi bir üst kurum olarak betimler (Davutoğlu, 1994: 235).

\section{Modern Öncesi Devlet Yapısı ve İktisadi İliş̧iler}

Modern devlet ile geleneksel dönem olarak adlandırılan modern öncesi dönemdeki devlet yapısı arasındaki ayrımlara bakıldığında İslam tarihindeki devlet pratiklerinin iktisadi ilişkileri belirlemesinde önemli ölçüde farklılıklar göze çarpar. Modern devletin tıpkı maksimum kâr arayıșında ve etkinlik esasına göre hareket eden bir şirket mantığında işlediği, üstelik bunu gerçekleştirirken mutlak egemen gücü sayesinde tüm iktisadi ilişkileri şekillendirdiği gerçeğinden yola çıkıldığında kapitalizmin bir sistem olarak küresel nitelik kazanmasında modern devlet mantığının payı büyüktür. Buna karşın, İslam siyaset düşüncesinde devlet aşkın ve soyut bir kurum olmanın ötesinde toplumsal iyiyi amaç edinen işlevsel bir siyasi üst kurumdur. İslam düşüncesinde devletin bu nitelikleri özellikle Endülüs, Selçuklu ve Osmanlı devlet tecrübelerinde açığa çıkmaktadır.

Osmanlı'nın devlet yapısı ve devletin toplumsal ve iktisadi hayattaki temel rolünü etkileyici bir şekilde ortaya koyan ünlü Osmanlı iktisatçısı Mehmet Genç Osmanlı devlet düzeninin iktisadi kalkınmada aldığı sorumluluk üzerinden İslam tarihindeki geleneksel devlet ile modern devlet arasında net bir ayrım yapmada oldukça faydalı bilgiler sunmaktadır. Buna göre, Batıda Aydınlanma ile başlayan ve beraberinde Fransız İhtilali ve Sanayi Devrimini doğuran ve kapitalist bir üretim tarzı ile yüksek refah üreten Batılı dünya görüşünde devletin üstlendiği rolü Osmanlı'nın hiçbir zaman benimsememesini ve bu değişime ayak uydurmamasını Osmanlı'nın farklı bir devlet tasavvuruna dayandıran Genç'e göre o dönem İslam dünyasında yaşanan göreceli geri kalmışlık bir zorunluluk olmaktan çok bilinçli bir tercihin sonucudur. Zira Osmanlı'nın benimsediği değerler sisteminde Batıdaki gibi bir devlet yapılanması ve iktisadi 
sistemin yer bulması imkansızdır. Bu manada Osmanlı’nın yaptığı Batının değişim rüzgârına ayak uydurmaktan çok bu değişime katılmayıp değişim karŞısında direnç göstermektir (Genç, 1987: 211-212).

İktisadi büyümenin vazgeçilmez bir şartı olan sermaye birikimi ele alındığında da benzer bir durum ortaya çıkmaktadır. Batı'da özellikle 13. ve 17. yüzyıllar arasında sermayenin sürekli büyümesi ve 18. yüzyıldan itibaren sermaye birikiminin zirveye ulaşmasıyla kapitalizmin taşıyıcıları olan uluslararası şirketlerin ortaya çıkması neticesinde yüksek refah üretilirken bunun dağılımsal uzantısı olan iktisadi adalet konusunda kapitalizm pek de başarılı bir sonuç ortaya koyamamıștır. Öncesinde tarımsal kapitalizm, daha sonra sanayi kapitalizmi ve nihayetinde finans kapitalizminin küresel dünyaya ödettiği bedelde modern devletlerin rolüne bakıldığında Osmanlı devlet tecrübesi sermaye birikiminin karşısında bir tavır sergilemiş ve toplum içerisinde iktisadi adaletsizliği doğuracak tüm sermaye birikimi ihtimallerini asgari düzeye indirme gayretine girmiştir (Genç, 1987: 216-217). Bunun için tarım arazilerinin özel mülkiyet kategorisinden çıkarılarak ziraatın küçük-orta büyüklükte bir çiftçinin işletebileceği ölçekle sınırlandırılması, esnaf teşkilatlarının kurulmasıyla şehirlerdeki ticarette yatırımcılar arasında büyük servet farklılaşmalarının önüne geçilmesi ve sermaye birikimi açısından kontrol edilmesi görece daha güç olan ticaret sektörüne narh uygulaması getirilerek tüccarların kar oranlarını \%5 ile \%15 arasında tutma politikalarının tamamında devletin sosyal ve ekonomik adaleti esas alan politikaları yatmaktadır (Genç, 1987: 219). Halbuki Batılı kalkınma hedeflerinin teorik arka planı sorgulanmadan bu hedefler kalkınma için evrensel standartlar olarak kabul edildiğinde az önce bahsedilenlerle birlikte Osmanlı'da vakıf uygulamasının serveti belli alanlara hapsederek etkin şekilde kullanmanın önüne geçtiği ve İslam miras hukukunun benzer şekilde servetin katlanarak büyümesine engel oluşturup servetin sürekli bölünmesine yol açtığı ve böylece Batıdaki gibi büyük şirketlerin refah üretmesine benzer bir politika doğurmadığı iddiaları (bkz. Kuran 2018; 2019) Osmanlı'nın Batılı ülkelere nispeten geri kalmasında etkili faktörler olduğu düşüncesini akla getirebilir.

Tüm bunlardan anlaşılacağı üzere, Osmanlının gayesi yaşanabilir bir sosyal ve iktisadi düzen kurmak ve bu düzenin istikrarını sağlamaktır. Devletin temel görevi ise bu düzenin sağlanmasında ve istikrarın korunmasında temelde güvenlik ve barışın tesisini öncelemektir. Modern devletin her alanı kuşatıcı ve denetleyici rolüne imkân veren egemenlik düşüncesinin aksine güvenlik alanının dıșındaki tüm sosyal refah sağlayıcı roller ise devletin doğrudan ilgi alanının dıșında olup sivil toplumun sorumluluk alanındadır.

\section{Devletin Egemenlik Alanı ve Sivil Hayat}

Modern devletin tek egemen irade olarak siyasi ve toplumsal hayatı şekillendirdiği bir dünyada sosyal refah araçları da yine modern devletin tahakkümü altındadır. Bu açıdan modern devlet için sosyal refah egemenliğin 
pekiştirilmesinde önemli bir araçtır. Eğitim, sağlık, altyapı hizmetleri, fakirlikle mücadele gibi temel refah alanlarındaki politikalar bir yandan müşfik devlet anlayışını sürdürmek amacıyla ortaya konurken diğer yandan bu alanlar iktidar mekanizmasının modern toplumları birer disiplin toplumu olarak dizayn etmesinde önemli işlev görürler (Foucault, 2006: 94).

Modern öncesi yakın dönem İslam tarihinde devlet ve toplum ilişkilerine bakıldığında sosyal refah sağlayıcı kurumlar olarak düşünülebilecek tüm kurumların büyük ölçüde sivil toplum tarafından organize edildiği görülür. $\mathrm{Bu}$ manada, modern devletin sonradan ihdas ettiği kurumlardan farklı olarak meşruiyetini doğrudan İslami prensiplerden alan zekât müessesesi ve faizin yasaklanması güçlü bir merkezi otorite ve iktidar mekanizmasına ihtiyaç duymaksızın sivil alanda fertler arasındaki ilişkiler sayesinde iktisadi adaleti sağlamak konusunda işlev görmektedir. Buradaki asıl gaye sermayenin belli ellerde toplanmasıyla ortaya çıkacak dağılımsal adaletsizliğin önüne geçmektir. Ayrıca zekât servet birikimini teşvik etmek yerine risk üstlenip sermayeyi ticarette dolaşıma sokarak haklı kazanç arayışı içerisine girmenin önünü açmıştır. Bu sayede, servetin atıl kalması yerine reel üretime katılması amaçlanmıştır.

Benzer şekilde vakıflar da sosyal kalkınmanın öncü kurumları olarak önemli bir rol icra etmiştir. Modern devletin toplumları disipline ettiği alanların tamamı vakıflarda bir sosyal ve iktisadi kalkınma potansiyelleri olarak görülür (Kozak, 1985). İslam tarihinde vakıf sayısı ve çeșitlerine bakıldığında toplumsal hayatın tüm çeşitliliğine hitap edebilen ve tüm canlı ve cansızlara yeryüzünde şeriatın maksatlarına uygun şekilde muamele edilmesinde vakıflar hayati rol üstlenmişlerdir. Böylece, farklı bir devlet tasavvuru ile şekillenen sosyal hayatta vakıflar günümüzün modern devletinin elinde iktidar sahaları olarak görülen tüm alanları kuşatmıștır.

\section{İslam İktisadının Kurucu Figürleri Açısından Devlet Düşüncesi}

Tarihsel süreç içerisinde devlet düşüncesinin dönüşümü ve günümüzde geldiği boyutlarıyla ulus devlet yapısının alternatifsiz bir devlet modeli olması 21. yüzyılda İslam iktisadı çalışmalarını da etkilemiștir. Son yüzyılda dekolonizasyon süreciyle birlikte bağımsızlı̆ını kazanan Müslüman toplumlar için egemenlik ve bağımsızlık ancak ulus devlet yapısı içerisinde bir serbestiyet alanı sağlar. Bu durumun farkında olarak yapılan ilmi çalışmaların birçoğu sömürgeci dönemde miras alınan devlet yapısını İslamileștirmek üzerine yoğunlaşmakla beraber iktisadi sahada da benzer șekilde İslami değerlerle yüklü bir ekonomik sistem inșa etme çabasına girmiștir. Özellikle 1950'li ylllardan itibaren İslam iktisadı üzerine farklı coğrafyalarda yapılan akademik çalışmalar temelde siyasi bağımsızlığın vermiş olduğu hareket alanıyla birlikte küresel ekonomik sistem içerisinde alternatif iktisadi çözümlere odaklanmıştır. Ancak bu süreçte siyasi bağımsızlığın sağladığı serbestliğe rağmen 
modern devletin Müslüman toplumları iktisadi olarak kuşatıcı rolü mevcut akademik çalışmalar arasında pek ilgi görmemiștir.

İslam iktisadının önde gelen figürleri bu süreçte modern devleti iktisadi özgünlüğü sağlamanın önünde önemli bir engel olarak görmekten çok ideal bir İslam devletinin olduğu atmosferde İslami bir iktisadi sistemin imkânı üzerine kafa yormuşlardır. Modern devlet olgusu bu yönüyle tahlil edilmesi gereken bir alan olmaktan çok tarih üstü bir gerçeklik anlayışıyla verili olarak kabul edilmiştir. Bu bölümde İslam iktisadının kurucu figürleri arasında yer alan beş önemli ismin İslam iktisadında devletin rolüne dair görüşleri Hallaq'ın sunduğu çerçeve üzerinden değerlendirilecektir.

\section{Umer Chapra'ya Göre İslam İktisadında Devletin Rolü}

Alandaki birçok eseriyle literatüre önemli katkılarda bulunan Chapra İslam iktisadının bir disiplin olarak ortaya çıktığı dönemde kurucu bir rol üstlenmiştir. Chapra'ya göre sosyal refah, adalet ve eşitlik temelli bir piyasanın oluşumu için piyasadaki tüm aktörlerin İslami prensipler tarafından belirlenmiş davranış kurallarına uymaları gerekir. Bu uyumun sağlanabilmesi beraberinde insanların arzuları ve özgürlügünün sınırlanmasına ve piyasadaki diğer oyuncular arasında bir çıkar çatışmasının önüne geçilmesine bağlıdır (Chapra, 2019: 5). Peki fertlerin davranışlarına sınır getirilmesi söz konusu olduğunda piyasadaki dengeyi ve uyumlu davranışları sağlayacak güç ne olacaktır?

Chapra'nın bu soruya cevabı "devlet" mefhumudur. Kendisi toplumun hedeflerine ulaşmada bir rehber olarak gördügü İslami idealleri gerçekleştirmek için devlete ihtiyaç duyar. Bu fikrinin temelinde Kur'an ve hadisler vardır. Bu iki ana kaynaktan devletin eğitim, teşvik ve caydırıcılık yoluyla üstlenmesi gereken görevleri olduğu fikrini çıkarır. Düşüncelerinde önemli bir yer edinmiş olan "denge" kavramı, devlete olan bakışında da etkin bir yer tutar. Chapra ne devlete pasif bir rol biçen yaklaşımları savunur ne de zulme neden olacak piyasaya keyfi bir müdahaleyi. Devletin aşırı müdahalesine karşı çıkar ve devlete başta aile olmak üzere kişilere ve topluma değerlerin, kurumların ve piyasaların etkileşim görevlerini verir (Chapra 2019: 77-79). Devletin baskıcı rolünü onaylamaz.

Chapra, dinin iktisadi hayattaki görevini ilk sıraya koyar. Ona göre din, maddi ve manevi ihtiyaçların nitelik ve niceliğini önemli ölçüde etkiler. İnsanın maddi ve manevi heves ve arzuları arasında denge kuran, insanın huzurunu ve aile ile toplum arasında dayanışmayı arttıran güç dindir. Ahlaki filtre sayesinde kişisel tercihler, toplumsal öncelikleri dikkate alacakken benzer şekilde toplumsal menfaat içinde de şahsi menfaatler korunacaktır. Böylece kişisel menfaat ve toplumsal menfaat arasındaki münasebet gelişmiş olacaktır. Chapra bunları ifade ettikten sonra can alıcı şu soruları sorar: Toplumsal olarak kabul gören bir ahlaki filtre olsa da başta zenginler ve güçlüler olmak 
üzere, kişilerin kendi menfaatleri ile çeliştiği durumlarda onların haklarından feragat ederek feda etmelerini teşvik eden dürtü nedir? Neden insanlar kendi faydasının aksi yönde bir davranışta bulunsun? Chapra'nın bu sorulara cevabı tek bir kavram üzerinde toplanır: İman. Dolayısıyla kişi, kaynaklar üzerindeki haklarının toplumsal menfaatle çatışma olması durumunda genel refah sınırları içerisinde kullanılmasına müsaade edecektir. Bununla birlikte iman, kişileri sade yaşama teşvik, israf ve gösteriş amaçlı tüketimden menetmeyi ve kaynaklar üzerindeki aşırı taleplerin azaltılmasını amaçlar. Bu ise tasarrufları arttırarak yatırımların çoğalmasına, işsizliğin azalmasına ve büyümenin artmasına neden olacaktır.

Peki burada devlet nerede durmaktadır? Sosyal hayatta kişiler aynı ahlaki bilinçte olmadığından iman doğal olarak tek başına piyasadaki aksaklıkları ve adaletsizlikleri ortadan kaldıramaz. Chapra, devlete tamamlayıcı bir rol biçer. $\mathrm{Bu}$ rol özel sektörün özgürlüğünü ve girişkenliğini gereksiz yere işgal etmeyecek bir yapıda olmalıdır. Devlet, toplum ahlakının temelini güçlendirmeli, buna uygun bir ortam hazırlamalı ve teşvikler ve cezalarla birlikte toplumsal hayatta dengeyi sağlamalıdır. Devletin piyasada rolünün azalması böylelikle kişilere bağlıdır. Çünkü İslami değerlere riayet edilirse ve kaynaklarla talep arasında adil bir denge sağlanırsa devlet de aradan çıkarak görünür olmayacaktır (Chapra, 2019: 119-123).

Chapra'nın devlete atfettiği rol genel manada modern dönemde tüm egemenliği kendisinde toplayan ulus devlet modelinin İslami bir versiyonunu bulma çabasıdır. Bu açıdan bakıldığında Chapra'nın ideal devleti Adam Smith'in görünmez eli ile benzer özellikler taşır. Smith'te toplumları bir arada tutan ve iktisadi ilişskileri de sağlam bir zeminde ulusal zenginliğe hizmet ettirecek mantık olan kişisel çıkar düşüncesi Chapra'da İman kavramına denk gelmektedir. Smith toplumun tüm fertlerinin kişisel çıkarı gözeterek hareket ettiğinde görünmez el yoluyla toplumsal çıkar ve dengenin sağlanacağını varsayarken Chapra da benzer şekilde ferdi düzeyde İman ile hareket eden fertlerin toplumsal hayatta dengeyi sağlayacağını iddia eder. Smith'te bu dengeyi sağlayan görünmez elin rolü bekçi devlet modelini ortaya koyarken Chapra'da görünmez el yerini müşfik devlet anlayışına bırakmıştır. Devlet burada önemli bir rol üstlenerek iman zayıflı̆̆ının toplumsal olarak kendini hissettirdiği alanlarda müdahaleci rolüyle dağıtıcı adaleti sağlar.

\section{Nejatullah Siddiqi'ye Göre İslam İktisadında Devletin Rolü}

İslam iktisadı alanının öncü isimlerinden biri olan ve alana önemli katkılarından dolayı da Faysal Ödülü'ne layık görülen Siddiqi devlet neden vardır sorusuna 'dayanışma' kavramı temelinden cevap verir. İnsanlar ihtiyaçlarını tek başına karşılayamayacağından toplum halinde yaşamaya mecburdur. Ferdi gayeler toplumdan bağımsız düşünülemez. Allah ise insanların ortak ihtiyaçlarını topluma emanet etmiştir. Dolayısıyla tek başına hayatını idame 
ettiremeyen insanlar için toplum ve toplumu düzene sokacak olan devlet kaçınılmazdır (Siddiqi, 2018: 11).

Siddiqi'ye göre İslam'da devlet mefhumunun temeli kişilerin temel yaşama standartlarını garanti altına almasıdır. Bu, șeriatın öncelediği meselelerinden biridir ve uygulanmaması halinde şeriatın amaçlarına tam manasıyla ulaşılamayacaktır. Buna ek olarak bu zaruri ihtiyaçları karşılamak zorunda olan devlet piyasadaki emtia fiyatlarına ve kaynakların tahsis edilmesi ile sonuçlanan piyasa süreçlerine minimum müdahalede bulunmalıdır. (Siddiqi, 2018: 13, 24).

Siddiqi ve Chapra'nın ortak düşünceleri vardır. Siddiqi Chapra'ya benzer şekilde zekât toplama görevini devlete verir, ama bu görevi çağdaş bir İslami devletin yapmak zorunda olduğu en asgari şey olarak görür. Eğer zekât yeterli olmazsa devletin ilave vergi almasında bir beis yoktur (Siddiqi, 2018: 25). Bir diğer benzer düşünce ise Siddiqi'nin adalete ve barışa olan güçlü vurgusudur. Siddiqi devletin asıl gayesi olarak bunları görür (Siddiqi, 2018: 40). Bu benzerliklere ek olarak güçlü bir demokrasiden yana olan Siddiqi kamu yararına ilişkin konularda halka danışılmasına mecburi görmektedir (Siddiqi, 2018: 41).

Siddiqi, İslam ümmetinin yaklaşık üçte ikisinin 50'den fazla ülke kurduğunu ve geri kalan üçte birlik kısmının ise başka ülkelerin vatandaşı olarak yaşadığını belirtir. Diğer bir yandan Hz. Peygamber döneminde Müslümanların tek bir siyasi liderlik altında yaşadığı gerçeği de vardır. Durum böyleyken İslami birlik ya da ümmet fikri açısından bu durum nasıl açıklığa kavuşacaktır? Siddiqi her ne kadar modern ulus devlet anlayışının İslam'a yabancı olmasını kabul etse de Müslüman devletlerinin kahir ekseriyetinin bu yönetim biçiminde olmasından dolayı bu tür devletlerin İslam hukuku çerçevesinde işlemesi koşulu ile kabul edilmesinden yanadır. Onun için aslolan şeriatın hükümlerinin uygulanmasıdır (Siddiqi, 2018: 100-101).

Siddiqi'nin bu düşüncesinin şeriatın modern devlet ve toplum içinde parçalı bir yapıda devam etmesi sorununu çözmek yerine farklı boyutlarıyla şeriat ve modernitenin yeniden bir arada bulunduğu hibrit bir sentezi mecbur kıldığı görülür. Modern ulus devlet anlayışı kendi kurumsal ve kuramsal çerçevesi neticesinde varlık gösterirken bu çerçevenin içinde şeriat mevcut durumdan farksız şekilde parçalı bir yapıda var olmaya devam edecektir.

\section{Sabahattin Zaim'e Göre İslam İktisadında Devletin Rolü}

İktisadi sistem tartışmalarının canlı olduğu bir dönemde Zaim bu tartışmalara Müslüman kimliğiyle katkılar sunmuştur. 1950’ler sonrası Türkiye’nin politik ve iktisadi dinamiklerinden etkilenen Zaim Türkiye'nin küresel ekonomiye dahil olmasını, ancak bu süreçte çağdaş kapitalizmin mülkiyet, servet, birikim emek ve fiyat gibi kavramlarını İslami bir dönüşüme uğratmak gerektiğini şart koşmuştur. Bu dönüşüm esasında iktisadi davranışın ve dolayısıyla kapitalist işleyişin kültürel kodlar vasıtasıyla yeniden sunumunu beraberinde getirmiştir (Bora ve Gültekingil, 2006). Buna örnek olarak Zaim'in 
homoeconomicus insan tipolojisine karşın homolslamicus tipolojisini öne sürmesi örnek gösterilebilir. Zaim'de çağdaş kapitalizmin kavramlarının kültürel kodlar yoluyla yeniden sunulmasıyla birlikte Zaim'in milliyetçi-muhafazakâr kimliğinin İslam iktisadı modelini önermesinde önemli etkisi olduğunu belirtmek gerekir. Türkiye'deki modernleşme tartışmalarının ilk yaklaşımlarından biri olan 'Batının kültürünü değil tekniğini almak' fikri yine milliyetçi-muhafazakâr kesimin yoğun olarak ilgi gösterdiği bir yaklaşımdır. Zaim de iktisadi özgünlük meselesine bu zaviyeden bakan isimlerdendir.

Yine buna başka bir örnek olarak Zaim'in Türkiye de kurulması için teşvikte bulunduğu özel finans kurumları verilebilir. "Zaim bu açıdan paranın dolaşım mekanizması, ticaret sistemleri ve teknolojik modernleşme unsurları konusunda Batıdan gelecek yeniliklere son derece açık, fakat kültürel ve ahlaki değerlerin alınmasını da yine aynı oranda eleştiren bir düşünür olmuştur" (Yorgancılar, 2018: 244). Ancak, teknik kavramının ve teknolojinin beraberinde taşıdığı anlam bagajındaki felsefi zemin belli bir ontolojiye dayanmaktadır. Dolayısıyla alınan teknik ve teknolojik unsurlar beraberinde bu ontolojiyi ve ahlaki yapıyı da içselleștirmek anlamına gelmektedir. Zaim'in bu yönü itibariyle iktisadi kalkınmayı sanayileşme, teknolojik ilerleme ve büyüme ile ilişkilendirmesi ve tüm bu süreçte devletin aktif rolünü vurgulaması modern devletin beraberinde getirdiği zorlukları aşma konusunda sınırlı bir çözüm sunmaktadır.

Öte yandan, Zaim'in düşüncesinde bireysel ve toplumsal yaşamın her alanında devlet oldukça ideal bir yapı olarak karşımıza çıkmaktadır. Devlet eğitimden sağlığa, ahlaki kazanımdan tüm sosyal hakların edinimlerine yani bireysel hayattan toplumsal hayatı kapsayan kısıtlamalara ve kazanımlara kadar oldukça güçlü bir düzenleyici konumdadır. Bu bakımdan Zaim'e göre herkesin iyiliğini önceleyen devletin en temel amacı İslami prensipleri toplumsal tabana yaymaktır. Devlet bu amacı gerçekleştirmek için ilgili müesseseleri ile sosyal hayatta varlık gösterir ve bireyi eğitir. Bununla beraber, Zaim insanın bilgili ve ahlaklı olmasının içinde bulunduğu cemiyeti geliştirdiğine ve insanın yetiştiği toplumun da bu sayede bilgi ve ahlak bakımından donanımlı olmasının önemine vurgu yapmaktadır (Zaim, 2010: 107). Burada Zaim Müslüman kimliği hasebiyle insanın ahlakını ve eğitimini din perspektifi dahilinde okumaktadır, fakat Türkiye'nin seküler bir devlet olarak kurulduğu ve buna bağlı olarak kurumsallaştığı göz önüne alındığında eğitim ve ahlakın kurumsallaşma sürecinin ne denli bu arka plandan koparılıp İslami bir çerçeveye oturtulabileceği sorunsalı hala karşımızda durmaktadır.

\section{Khurshid Ahmad'e Göre İslam İktisadında Devletin Rolü}

Ahmad, Batı uygarlığını temel olarak din-devlet ayrilığı üzerinden tasvir ederken İslam’ı Batı uygarlığından ayıran temel farklılığı din-devlet ilişkilerinin mahiyeti üzerine temellendirmektedir. Ona göre Batıdaki din-devlet ayrılığı sosyal, ekonomik, politik ve teknolojik meselelerin tamamında metafiziksel 
bir anlatıyı reddeder. Bir Tanrının varlığı kabul edilse dahi bu Tanrı bilimsel dünya sahnesinde yer almayan, gelişmeleri uzaktan izleyen pasif bir nesnedir (Ahmad, 2019:1). Devlet ise burada insanlığın tarih sahnesinde ilerlemesinin önünü açıcı bir yapı olarak karşımıza çıkar. Dolayısıyla, devlet de din ile arasına koyduğu mesafeyi korumak mecburiyetindedir. Diğer türlü, Orta çağ karanlık yüzyılında başrolleri oynayan din ve devlet birlikteliği ve çıkar birliği modern çağda yeni bir karanlık dönemin açılmasına sebep olabilir.

Batıda dine dayalı metafizik anlatıları reddeden ve devleti dinin etki sahasından ayrıştıran yaklaşım karşısında Ahmad İslam'da devletin dinin amaçlarını yerine getirmede önemli bir rol oynadığını iddia eder. Bu yönüyle devlet sosyal refahı sağlamada önemli bir görev üstlenir. Buna göre devlet zenginlerin âtıl kalan servetini veya birikimini zora başvurarak alabilir ve sosyal adaleti, gelir eşitsizliğini ve sosyo-ekonomik dinamizmi hareketlendirmeyi gerçekleştirebilir. Refahın sağlanmasında devlet ayrıca mali politikalara başvurarak vergiler üzerinden ek gelir yaratabilir (Ahmad, 1981: 14-15).

Ahmad'in devlete bu derece kapsamlı bir rol vermesinde Pakistan'ın sömürge sonrası dönemde şahit olduğu İslami devlet arayışlarının etkisi çok büyüktür. Zira, hızlı bir İslamileştirme sürecine girmesi gereken Pakistan'da iktisadi, siyasi ve sosyal dönüşümü çabucak sağlama gücüne ve yetkisine sahip olan tek kurumun devlet olduğuna inanılır. Bunun için de herkesin iyiliğini düşünen ve kadiri mutlak bir devlet anlayışı gerekir. Ahmad her ne kadar İslami devleti kapitalizmde görülen "bırakınız yapsınlar" mantığındaki bir devlet ile totaliter bir yapıya sahip olan sosyalist devlet modeli arasında bir yere konumlandırsa da (Ul-Hassan, 2010: 227), bu yaklaşımıyla yapısı ve işlevi bakımından hem kapitalist hem de sosyalist nitelikler barındıran modern devletten farksız bir İslami devlet tahayyül etmiştir. Toplumun tabanından yayılan bir sivil hareketin getireceği İslami dönüşüm yerine, Ahmad modern devlet gibi tepeden inmeci bir mantıkla hareket ederek İslamileştirme sürecinin tüm sorumluluğunu devlete yüklemiştir (Bhat, 2016: 6). Bunun gerekçesi olarak da bir alanda yaşanacak İslami dönüşümün başka alanlarda görülmemesi üzerine ortaya çlkacak olan karmaşanın önüne geçmek için devletin yukarıdan müdahalesinin kaçınılmazlığına işaret etmektedir.

\section{Haider Naqvi'ye Göre İslam İktisadında Devletin Rolü}

Naqvi, İslam devletinin lüzum gördüğü hadiseler karşısında düzeltici aksiyomlar geliştirmesini ahlaki olarak zorunlu görür. Örneğin, özel mülkiyet hakkını toplumdaki diğer kişilerin faydasına zarar verecek şekilde suistimal eden bir iktisadi aktör karşısında devlet ıslah edici düzenlemelerde bulunmalıdır. Bundan dolayı devlet için tarafsızlık denen bir olgu söz konusu olamaz, çünkü ortada adil ve adil olmayan iki olay vardır. Bu da göstermektedir ki İslam'ın iktisadi prensipleri neoklasik iktisattaki verimlilik esaslı yaklaşımı iktisadi davranıştaki yegâne kriter olarak belirme üzerine değil, adalet esaslı yaklaşım tesis etme üzerine kuruludur (Naqvi, 2018: 45). 
İslam iktisadının normatif boyutuna odaklanan Naqvi'ye göre İslam iktisadı sadece mülkiyet haklarını tartışmaz, İslam'da devlet yeri geldiğinde özel mülkiyet haklarından dolayı ortaya çıkan toplumsal ahengi bozacak durumların düzeltilmesini de sağlar. 0 , İslam ahlakının doğuştan gelen ferdi özgürlük ile toplumsal sorumluluğunun birlikte olduğu hususunun önemini belirtmekle birlikte belirli kurallar çerçevesinde bireyin ekonomik özgürlüğünün garanti edilmesini, bireysel özgürlügün toplumsal refah ile çelişkiye düştüğü durumda devletin müdahalede bulunması gerektiğini savunur (Naqvi, 2018: 45, 53).

Naqvi'ye göre, sosyalizm ve kapitalizm gibi refah devleti anlayışı da İslam iktisadı ile ortak bir zeminde buluşturulamaz. Mahiyeti itibariyle adalet yanlısı olan ve İslam iktisadına en çok yakıştırılan refah devleti anlayışı 'herkesten yeteneğine göre, herkese ihtiyacına göre' prensibini kabul ettiğinden küçük bir grubun kazanma yeteneği ve sosyal hayattaki her bireyin sahip olduğu asgari hayat düzeyi arasında bir ayrım yapmaktadır. Bu doğrultuda kapitalist bir serbest piyasada üretim ve tüketimi düzene sokmak için devlet müdahalesi gerekli hale gelmiştir. Denge ilkesi çerçevesinde 'orta yol' üzerinde ilerlemeyi hedefleyen İslam iktisadının ahlaki temeli ise devletin yaptırım gücüyle insanların gönüllülük duygularını birleștirmektir. Her iki görüş aynı yönü göstermesine rağmen İslam, devleti ve bireyi bir araya getirme çabası içinde olduğundan ve daha büyük bir güçle bu yönde hareket ettiğinden refah devleti anlayışından farklılaşmaktadır (Naqvi, 2018: 80-81).

Naqvi'ye göre devlet iktisadi faaliyete düzenleyici olarak müdahil olur. İslam özel mülkiyete dokunmaz ama ondan kaynaklanan gelirlerin harcanması konusunda bağlayıcı kısıtlar koyar. Ne tek başına devlet müdahalesi toplumun menfaatini temsil eden bir göstergedir, ne de serbest piyasa sistemi bireysel özgürlüğün teminatıdır. Naqvi bu iki görüşün birleşmesi yönünde kanaat bildirir. Ona göre toplumsal refahı maksimize edecek olgu devlet kontrolü ve serbest girişimin sulh yoluyla bir araya getirilmesidir. Ana hedef ekonomik büyümeyi dağıtıcı adalet ile taçlandırmaktır (Naqvi, 2018: 104).

Naqvi, öte yandan, ahlak kavramının ekonomiden ayrı düşünülemeyeceğini belirtir ve kurduğu temel aksiyomunu bunun üzerine bina eder. İslam'ın ekonomi anlayışını sosyalizm ve kapitalizmden farklı bir konumda gören Naqvi devletin ekonomiye bakışını da yine aynı şekilde diğer iki sistemden ayrı tutar. 0 , ne sosyalizmde olduğu gibi devletin mutlak müdahalesini ne de kapitalizmde olduğu gibi devletin fazlaca görünür olmamasını onaylar. Adaleti temel mihenk taşı olarak kabul eder ve devletin adalet çerçevesinde piyasayı etkileyeceğini iddia eder. Talegani ve Bakır es-Sadr gibi devletin gerektiğinde piyasaya müdahil olması gerektiğini savunan düşünürlerden etkilenmesi onun devlete aktif bir rol vermesinde etkili olmuştur. Öte yandan Hallaq'ın üzerinde titizlikle durduğu ahlak prensibi Naqvi'nin çalışmalarında da önemli bir yere sahiptir. Sağlam ahlaki temellere sahip olunmayan bir sistemin başarılı ve sürekli olamayacağı görüşü her iki düşünürde de ortaktır. 


\section{İslam İktisadı ve Modern Devlet: İmkansızlıktan Çıkış Yolu Aramak}

1950'li yıllardan itibaren siyasi bağımsızlığın vermiş olduğu serbest hareket alanı Müslüman toplumları bir arada tutacak olan bağın nasıl kurulacağına dair sorgulamaları arttırmıştır. Eski sömürgeci mirasa dayanan toplumsal ilişkilerde piyasa sistemi toplumsal ilişkileri düzenlemede mübadele kurallarını esas almıştı. Bireysel güvensizlik üzerine kurulu olan bu felsefede toplumsal uyum ancak piyasanın tam denge halinde işlemesine bağlıdır. Müslüman kimliği açısından varoluşsal sorunları beraberinde getiren bu mirasın terk edilmesi çabaları İslami değerlerin modern dönemde yeniden yorumlanmasıyla oluşturulacak bir değerler sisteminin belirleyeceği toplumsal ilişkileri ve bağın kurulmasının önünü açmıştır.

İslam iktisadı çağdaş dönemde Müslüman toplumların üzerinde mutabık kalacağı bir toplumsal düzen inşasında iktisadi sahadaki arayışın bir karşılığı olarak karşımıza çıkmıştır (Asutay ve Yılmaz, 2018: 373). Kapitalist sistem toplumsal bağ sorununu serbest piyasanın belirlediği mübadele kurallarının bireysel ve toplumsal alanda uygulanmasını şart koşarak kendince çözüme kavuştururken bu süreçte devlete ancak piyasanın kendi kendine kusursuz işleyişini bozmayacak bir hareket alanı tanımıştır. Toplumsal ilişkilerin belirlenmesinde birey, toplum, piyasa ve devleti kendi içerisinde konumlandıran neoklasik iktisadi düşünce karşısında modern dönem İslam iktisadı çalışmalarında piyasa ve devlet ilişsileri bakir kalmış sahalardan biridir.

Mübadele koşullarının toplumsal ilişkileri belirlemede yegâne merci olması karşısında İslam iktisadı toplumsal uyumu ve birlikteliği ahlaki bir piyasanın varlığına bağlar. Kurucu figürlerin yaklaşımında ortak olan husus burada ahlaki piyasanın inşa edilememesi durumunda müşfik bir İslami devletin bu açığı kapatmasıdır.

Devlete temelde ahlaki bir piyasanın işlerliğini sürdürme rolü veren ve devletin düzenleyici ve refah dağıtıcı özelliklerini vurgulayan İslam iktisadı çalışmaları devleti tarihsel zemine oturtarak modern devletin piyasa ile etkileşimini ve ahlaki bir piyasanın inşa edilmesinde devletin önleyici ve ifsat edici boyutlarını pek fazla gündeme getirmemiştir. Hallaq'ın vurguladığı üzere modern dönemde İslami bir devletten bahsetmenin imkansızlığı beraberinde İslami bir piyasayı ve daha genelde İslami bir iktisadi sistemin varlığını da imkânsız kılmaktadır. Zira, iktisadi ilişkiler toplumsal ilişsilerden ve dolayısıyla devletin de içinde olduğu kurumlardan bağımsız düşünülemez.

Hallaq'in güçlü tezleriyle savunduğu imkânsız devlet düşüncesi karşısında yapılması gereken şeyin bu durumu kabullenmek ve kaderci bir anlayışla mevcut duruma razı olmak gerektiği akla gelebilir. Eserde Müslüman toplumların İslami bir yönetimi modern çağda kurabilmesi için en temelde güçlü emperyalist devletlerin militarizmi, dış kaynaklı kültürel müdahaleler ve liberal-kapitalist dünya pazarının yarattığı politik ekonomi sistemiyle hesaplaşması ve 
bunlara karşı çözüm üretmesi gerektiği iddia edilir. Ancak, eser neticede somut bir öneri ve gelecek tasavvuru sunmada okuyucuları kendi yorumlamalarına bırakmaktadır. Bu açıdan Hallaq'ın eseri Müslüman toplumların siyasi olarak içinde bulundukları durumu oldukça kapsamlı bir şekilde açıklamaktayken, bunun ötesine geçen bir öneri sunmakta oldukça sınırlı argümanlara sahiptir.

İslam iktisatçlarının Hallaq'ın kapsamlı şekilde belirttiği temel zorluklar ve hesaplaşmalara nasıl bir yaklaşım geliştireceği alanda yapılacak gelecek çalışmaları açısından oldukça önemlidir. İslam iktisadının en merkezi hususları arasında piyasa-toplum, piyasa-hukuk ve piyasa-devlet ilişkileri olduğu düşünülürse modern devletin İslami bir piyasanın oluşumundaki engelleyici rolü İslam iktisadının mağduru olduğu imkansızlığın aşılması açısından araştırmaya değerdir.

Modern devletin sahip olduğu engelleyici özellikler karşısında modern çağda Müslüman kimliğini yaşatmak ve toplumsal boyutta İslami değerler taşıyan kurumlar inşa etmenin zorluğu ya da imkansızlı̆̆ özellikle Türkiye tecrübesinde görülmektedir. Halifeliğin kaldırıldığı bir coğrafyada İslam'ın politik, iktisadi, sosyal ve hukuki olarak kurumsallaştığı yapıların yerini seküler kurumların alması ile birlikte devlete olan yaklaşım Cumhuriyetin ilk yıllarında daha çok tekfir edici bir tutumu beraberinde getirmişti. Müslüman kimseler için yeni Türkiye Cumhuriyeti İslami değerlerden uzak bir toplumsal birliktelik amaçlamaktaydı ve Müslümanlar da bu durumun farkında olarak toplumsal hayatın tüm alanlarından büyük ölçüde uzak durmaktaydı. İslami değerler ise ancak sivil toplum sayılabilecek cemaatler üzerinden periferide yaşanıyordu.

1920 ile 1945 yılları arasında Müslüman kimliğini ön plana çıkaran insanlar ile seküler devlet arasında mesafeli bir tutum mevcuttu. Ancak bu zamandan sonra siyasi iktidarların toplumsal hayatta ve kurumlarda İslami değerleri araçsallaştırarak da olsa gündeme getiren yaklaşımları seküler devlet olgusunun yerini yavaş yavaş İslami değerleri de dikkate alan demokratik ve sosyal refahı gözeten devlete bırakmaya başlamıştır. Özellikle Adnan Menderes, Necmettin Erbakan ve Turgut Özal dönemlerinde uygulanan politikaların Müslüman fertler nezdinde İslami bir devletin imkânı konusunda oldukça heyecanlandırıcı bir etkisi olmuştur. Böylece siyasi partilere oy vermeyi küfür ile eşit tutan anlayış yerini siyasetin içinde Müslüman politikacıların etkin olduğu ve devletin bir şekilde İslamcı kimlikler tarafından temsil edildiği bir sürece bırakmıştır. Bu süreçte temel beklenti özü itibariyle İslami değerlerden uzak olan seküler devleti İslamileștirmek olmuştur.

Şerif Mardin'in Türk siyaseti için kullandığı merkez-periferi ilişkileri perspektifinden bakıldığında (Mardin, 2020) Cumhuriyetin kurulmasından itibaren periferide yer alan İslami grupları 1960'lı yllardan itibaren giderek merkezin alanına girmeye başlamasıyla uzun vadede İslami grupların merkezin tamamını kaplayarak İslami bir devleti tatbik etme hayali vardır. 21. yüzyılın 
başında bu beklenti siyasal İslam düşüncesinin iyice yerleştiği bir dönemde zirveye ulaşmıştır. İslami değerlerin modern devlet yapısında içselleştirilmesine dair beklenti bu dönemde tutkulu bir şekilde ifade edilmiştir. Ancak, modern devletin bu çalışma boyunca etraflıca açıklandığı boyutları dikkate alındığında İslami değerlerin politik düzlemde modern devletin engelleyici yönlerine bir çözüm getirmekten çok modern devletin merkezde yerini koruyarak periferinin merkeze taşıdığı tüm değerleri kendi bünyesinde dönüştürdüğü ve etkisizleștirdiği görülür.

Son yüzyılda siyasi arenada gerçekleşen durum periferinin giderek merkezin seküler yapısını İslamileştirmesinden çok merkeze gelen siyasi iktidarların modern devletin temel bileşenlerini yapı çözümüne uğratmadan periferideki İslami grupları modern devlete adapte etmesidir. Menderes döneminde başlayan ve Erbakan ile Özal dönemlerinde periferiden merkeze doğru giderek daha geniş katılımların olmasıyla merkezin dönüştürdügü ve kendi potasında erittiği İslami kimlikler 21. yüzyılın başlarındaki İslamcı siyasetle birlikte merkezi temsil eden bir boyut kazanmıștır. Bu anlamda, merkezin etki alanında kalmayan periferinin son İslami grupları da modern devletle barışmış ve merkeze taşınmıştır. Artık periferide kalmayı tercih eden İslami cemaat ya da grupların sayısı giderek azalmış ve dolayısıyla İslami bir sivil toplumun modern devlet karşısındaki dönüştürücü etkisi önemini yitirmiştir.

Bugün her ne kadar merkezin İslamileștiği ve seküler devlete tehdit sayılabilecek bir yola doğru gidildiği düşünülse de kurumları ve işleyişi itibariyle neoliberal devletten hiçbir şekilde ödün vermeyen ve merkezde her ideolojiyi kendi çıkarları doğrultusunda öğüten bir modern devlet karşımızda durmaktadır. İktisadi yönleriyle bakıldığında neoliberal İslam'ın iktidar olduğu bir modern devlet yapısını içselleştirmiş bir mantığa göre devleti tartışmak yersiz olacaktır, zira devlet tabiri yerindeyse 'ceptedir'. Bu anlayış sebebiyle İslam iktisadı çalışmaları modern devleti ele almakta oldukça isteksizdir. Devletin İslamileştirilmesi sonrası sıra piyasayı İslamileştirmeye gelmiştir. Bunun için de neoliberal iktisadi politikaların İslami bir dekorla süslenmesi gerekmektedir. İslam iktisadında ana yönelim bu misyonu icra etmeye odaklanmiștır.

\section{Sonuç Yerine: Bazı Öneriler}

Son yüzyılda Türkiye özelinde görülen bu tecrübeler diğer Müslüman toplumlar için de benzer sonuçlar doğurmuştur. Modern devletin yapısı itibariyle ele alınmasından çok neoliberal iktisadi sistemi İslamileştirme çabaları İslami finans yoluyla gerçekleştirilmektedir. Bu durumdan çıkış yolu modern devleti tekrar iktisadi analize dahil etmekten geçer. Sivil toplum altında sayılabilecek kurumların inşa edilmesi devletin ekonomideki baskın etkisini seyreltecek bir etki yaratabilir. Özellikle risk paylaşımını esas alan, ortaklığa dayalı ve paylaşım temelli bir iktisadi sistem için gerekli olan kurumsal yapı sivil toplum içerisinde inşa edilebilir. Finansallaşmanın yeni küresel iktisadi 
amaç olduğu bir dünyada finansman ihtiyaçlarını dayanışmayı esas alan ve paylaşım odaklı sivil yapılar yoluyla kuran ara kurumlar sayesinde devletin nüfuz alanı daraltılabilir. Temelde güvenliği ve hukuki düzeni amaçlayan devletten bireysel ve toplumsal hayatının en ücra köșelerini dahi dizayn eden bir devlet anlayışına geçiş ne kadar zaman aldıysa bu dönüşümlerin tekrar gerçekleşmesi için de en az bu süre kadar beklenmesi ve çaba gösterilmesi gerekmektedir, zira toplumsal geçişler mekanik bir sürece bağlı olan değișimler değildir.

İslam iktisadı mevcut yönelimine rağmen küresel dünyada ana akım iktisadın karşısında değerleri itibariyle bir alternatif sunabilecek kapasiteye sahiptir. Bunun için kavramsal ve kurumsal bir yeniden gözden geçirme kaçınılmazdır. İslam iktisadında her ne kadar yönelim İslami finansın geliştirilmesine ve küreselleşmesine odaklansa da özgün bir iktisadi sistem için öncelikle ana akım iktisadın belirlediği ve verili olarak kabul edilen kavramların tekrar sorgulanmasına ihtiyaç vardır. Bununla birlikte, kurumların da benzer şekilde iktisadi sistemle olan ilişkisi yeniden dikkate alınmalıdır.

\section{Kaynakça}

Ahmad, K. (1970). The religion of Islam. Lahore: Islamic Publication.

Ahmad, K. (1981). Towards the monetary and fiscal system of Islam. Islamabad: Institute of Policy Studies Islamabad.

Ahmad, K. (Ed.). (2019). İslam iktisadı çalışmaları. (Çev. F. Yozgat). İstanbul: İktisat Yayınları.

Althusser, L. (1994). İdeoloji ve devletin ideolojik aygıtları. (Çev. A. Tümertekin). İstanbul: İletișim Yayınları.

Anderson, B. (1995). Hayali cemaatler: Milliyetçiliğin yayılması ve kökenleri. İstanbul: Metis Yayınları.

Arslan, A. (2015). Modern dünyada Müslümanlar. İstanbul: İletişim Yayınları.

Asutay, M. ve Yllmaz, İ. (2018). Re-embedding Maqasid al-Shari'ah in the essential methodology of Islamic economics. M. T. El-Mesawi (Ed.). Maqasid al-Shari'ah: Explorations and implications içinde (373-418. ss.). Kuala Lumpur: Islamic Book Trust.

Bhat, N.N. (2016), The economic thought of Khurshid Ahmad, Turkish Journal of Islamic Economics, c. 3(2), 1-11.

Bora, T. ve Gültekingil, M. (Ed.). (2006). Modern Türkiye'de siyasi düşünce: muhafazakarlık. İstanbul: İletişim Yayınları.

Chapra, U. (2019). İslami refah devleti ve ekonomideki rolü. K. Ahmad (Ed.), Íslam Íktisadı Çalışmaları içinde (221-259.ss.). İstanbul: İktisat Yayınları.

Davutoğlu, A. (1994). Devlet. Türkiye Diyanet Vakfı Iislam ansiklopedisi içinde (Cilt 9, 234-240.ss.). İstanbul: Türkiye Diyanet Vakfi.

Erdoğan, M. (2006). Aydınlanma, modernlik ve liberalizm. Ankara: Orion Kitabevi. 
Ergut, F. (2015). Modern devlet ve polis: Osmanlı'dan Cumhuriyet'e toplumsal denetimin diyalektiği. İstanbul: İletişim Yayınları.

Ertugay, F. (2016). Devletin totaliterliğine itiraz: Muhafazakârlık ve ara kurumlar. $M u-$ hafazakâr Düşünce, 12(47), 159-180.

Foucault, M. (2006). Hapishanenin doğuşu, (Çev. M. A. Kılıçbay). Ankara: İmge Kitabevi.

Genç, M. (1987). Kalkınma meselemize tarihi bir yaklaşım, Kolektif (ed.), Íktisadi Kalkınma ve İslam, İstanbul: Ensar Neşriyat, ss. 211-226.

Hallaq, W. (2019). Imkânsız devlet: Modern çağda bir islam devleti niçin mümkün değildir?. (Çev. A. Hikmet). İstanbul: Babil Kitap.

Karpat, K. (2002). Osmanlı modernleșmesi toplum, kurumsal değişim ve nüfus. (Çev. A. Z. Durukan, K. Durukan). İmge Kitabevi, Ankara.

Kozak, İ. E. (1985). Bir sosyal siyaset müessesesi olarak vakıf. İstanbul: Akabe.

Köse, H. M. (2018). İslam siyaset düșüncesinin temelleri: bir giriș denemesi, L. Sunar ve Ö. Kavak (Ed.). İslam siyaset düşüncesi: Adil devlet, erdemli şehir, mükellef insan içinde 27-51. ss). İstanbul: İlem Yayınevi.

Kuran, T. (2018). Yollar ayrılırken: Ortadoğu'nun geri kalma sürecinde İslam hukukunun rolü. (Çev. N. Elhüseyni). İstanbul: Yapı Kredi Yayınları.

Kuran, T. (2019). İslam ve ekonomik azgelişmişlik: tarihsel ve çağdaş bağlantılar. İstanbul: Efil Yayınları.

Mardin, Ș. (2020). Türk Modernleșmesi. İstanbul: İletişim Yayınları.

Naqvi, S. N. H. (2018). Íslam, ekonomi ve toplum. (Çev. O. Maraşlı). İstanbul: İktisat Yayınları.

Özel, A. (2019). Dârülislam dârülharb: İslâm hukukunda ülke kavramı. İstanbul: İz Yayıncilık.

Poggi, G. (2008). Devlet: Doğası, gelişimi ve geleceği. (Çev. A. Babacan). İstanbul: İstanbul Bilgi Üniversitesi Yayınları.

Schmitt, C. (2007). The Concept of the political. (Çev. G. Schwab). Chicago: University of Chicago Press.

Siddiqi,M. N. (2018). Ekonomide devletin rolü: İslami bir bakış. İstanbul: İktisat Yayınlarl.

Ul-Hassan, M. (2010). Islamic approach of economics: some discourses on Khurshid Ahmad's vision of socio-economic order, self-reliance and economic development. Kyoto Bulletin of Islamic Area Studies, 3(2), 216-240.

Vatikiotis, P. J. (1998. İslam ve ulus devlet. İstanbul: Pınar Yayınları.

Yorgancılar, S. (2018). Muhafazakâr modernleșme: Sabahattin Zaim üzerinden bir değerlendirme. Uluslararası İnsan Çalışmaları Dergisi, 1(2), 235-245.

Zaim, S. (2010. İslam ve İktisadi Nizam. Eskiyeni, 18(1), 106-118. 